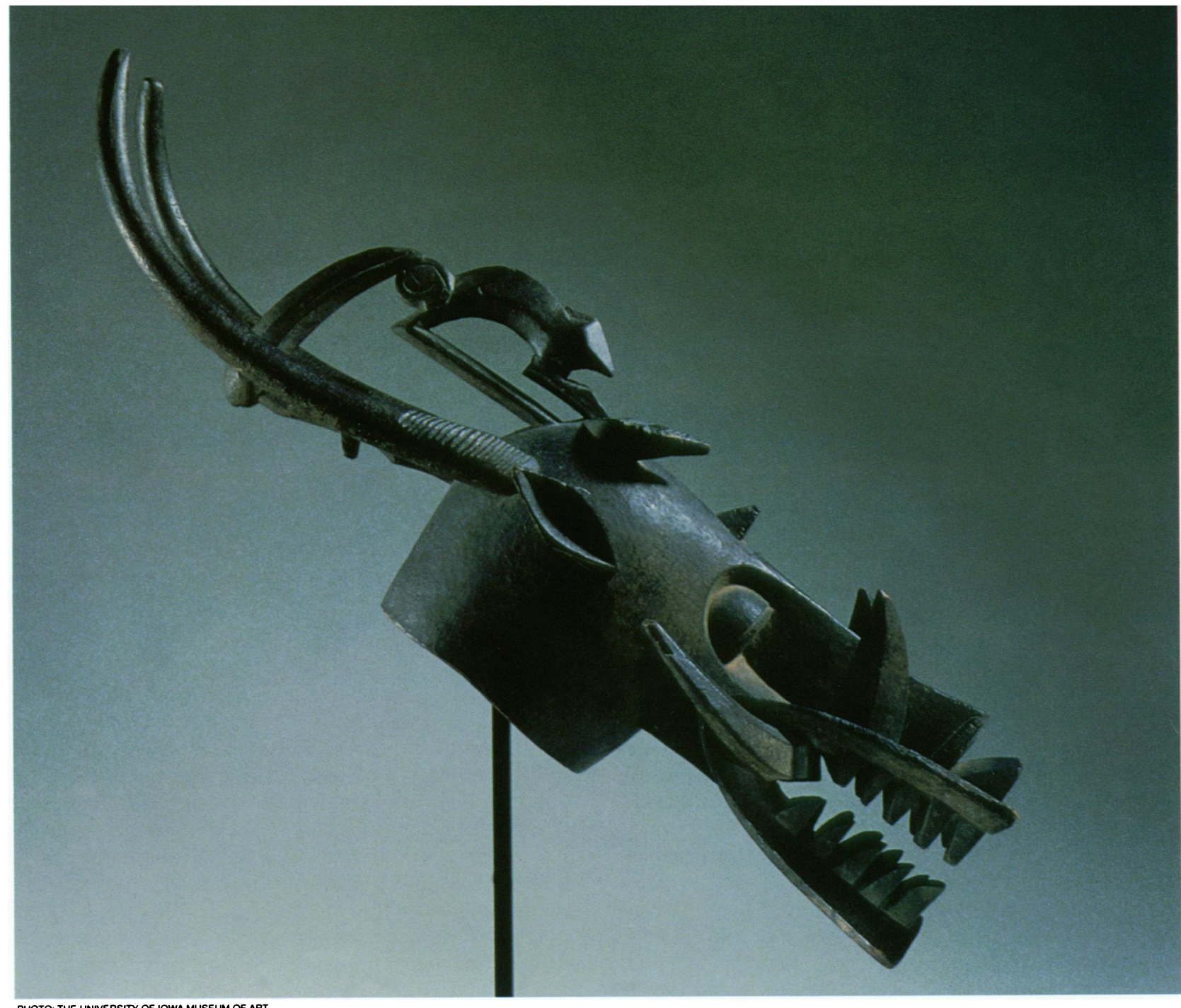

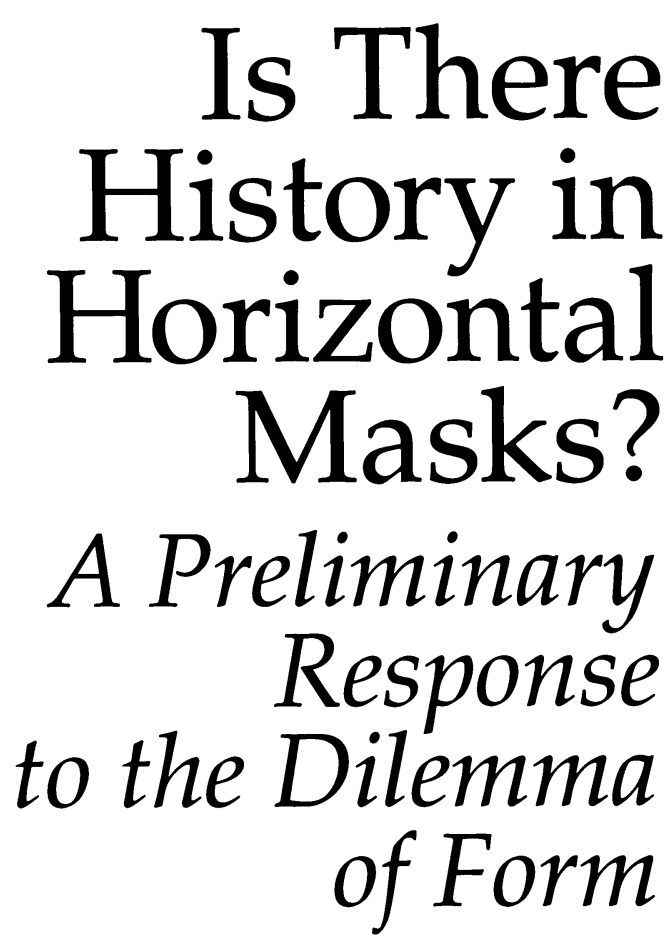
History in Horizontal Masks?

PATRICK R. McNAUGHTON

I was an early Arnold student, the result of his three non-Western survey courses. As an undergraduate senior I had taken classes in Eastern and all sorts of Western art, but I had never thought about or really even looked at the arts of Africa, the Americas, or Oceania.

Arnold was electrifying. For me he showed how complex artworks could be, how they were both intellectual and visceral, dramatic and subtle. He made art's importance evident, and I appreciated that immensely. By then I had taken several studio courses, and I was nearly committed to graduate school in design. Arnold converted me.

As a first-year graduate student with him, I remember our lively and provocative seminars, and all the special speakers he brought for us to experience. But I also remember afternoons and weekends, going with him to used-book stores and a gun shop where wonderful African iron works had ended up for sale. We went to a giant warehouse of old books in Long Beach. I grew up in L.A. but had never gone to the place. He on the other hand had arrived from the Midwest and made a beeline for it, and so could take his graduate students directly to the spot where some six copies of The Secret Museum of Mankind sat patiently. These sorts of things, combined with my time with Arnold on campus, made being his student especially memorable. 
$\mathrm{T}$ he contemplation of forms has inspired this essay, causing me to question how the masks discussed herein came to occupy their present conceptual and cultural space. The answer, if there is one, lies in future research, which I hope will contribute to a richer reconstruction of African art history.

Form and distribution studies are today a dangerous business for art historians, since in isolation they ignore so many kinds of data and new research perspectives. But they can be useful to formulate art historical issues and problems that warrant in-depth exploration.

There are hundreds of masking traditions in sub-Saharan Africa, but nearly all are based on a mere handful of formal configurations: headdresses (Bamana $\mathrm{C} i$ wara, for example), helmet masks (as in Yoruba Epa), face masks (such as Lwalwa Ngongo association masks), and masquerade constructions (from simple Middle Benue net costumes to elaborate Igbo Ijele multi-media creations). Out of these rudimentary structures emerge three-dimensional compositions of astounding variety-a mosaic of forms that occur in seemingly random geographic patterns that have been changing and flowing for so long that historical reconstructions of their occurrence within any definable unit (region, ethnic group, even single town) are exceedingly difficult.

Two of these rudimentary structures, the helmet and, less frequently, the headdress, provide the foundation for a constellation of masks used widely across West Africa. They generally suggest animals, usually wild animals (such as bush buffaloes) and often more than one simultaneously in a composite composition. Very abstract, and most frequently divided into three compositional segments, these sculptures project, often dramatically, away from the vertical axis. Thus they are often called horizontal masks, although several examples are worn diagonally. They are strikingly different from other helmet masks or headdresses, as well as from face masks and masquerade constructions.

While the appearance of these horizontal masks varies greatly, there is also a pronounced degree of unity. And because the masks are each complex cultural forms vitally affiliated with many

OPPOSITE PAGE: 1. HELMET MASK, KPONYUNGO SENUFO, COTTE D'IVOIRE/BURKINA FASO. WOOD, LENGTH $104 \mathrm{~cm}$.

THE UNIVERSITY OF IOWA MUSEUM OF ART, IOWA CITY, THE STANLEY COLLECTION (X1986.533). elements in their social realities, this unity prompts a question worthy of further examination. Is it possible that the visual similarities in these masks are not just happenstance, but rather the result of a history we might begin to understand?

The masks are used across nearly 3,000 miles of West and Central Africa, covering a wide variety of ecologies, by members of eight language or culture affiliations who belong to some seventyeight ethnic groups (see Fig. 3). At one end of this range are the Baga versions in Guinea. Near the eastern end are the Jukun, Chamba, and Cameroon Grasslands versions. Further east, in the Chari and Ubangi river basins, the Sara Mbaye and Manja extend the geographic range of the horizontal mask into the northern savanna of Central Africa.

Several scholars have written about these masks. In 1962 Douglas Fraser published "The Legendary Ancestor Tradition in West African Art." Confining himself to certain examples in the western area, he cast a very esoteric net in a preliminary effort to link the sculptures' functions and meanings. One year later Monni Adams submitted a master's thesis to Fraser titled "The Distribution and Significance of Composite Animal-Headed Masks in African Sculpture," which emphasized horizontal masks. Her mission was not historical reconstruction. Rather, she wanted to demonstrate a basic unity in

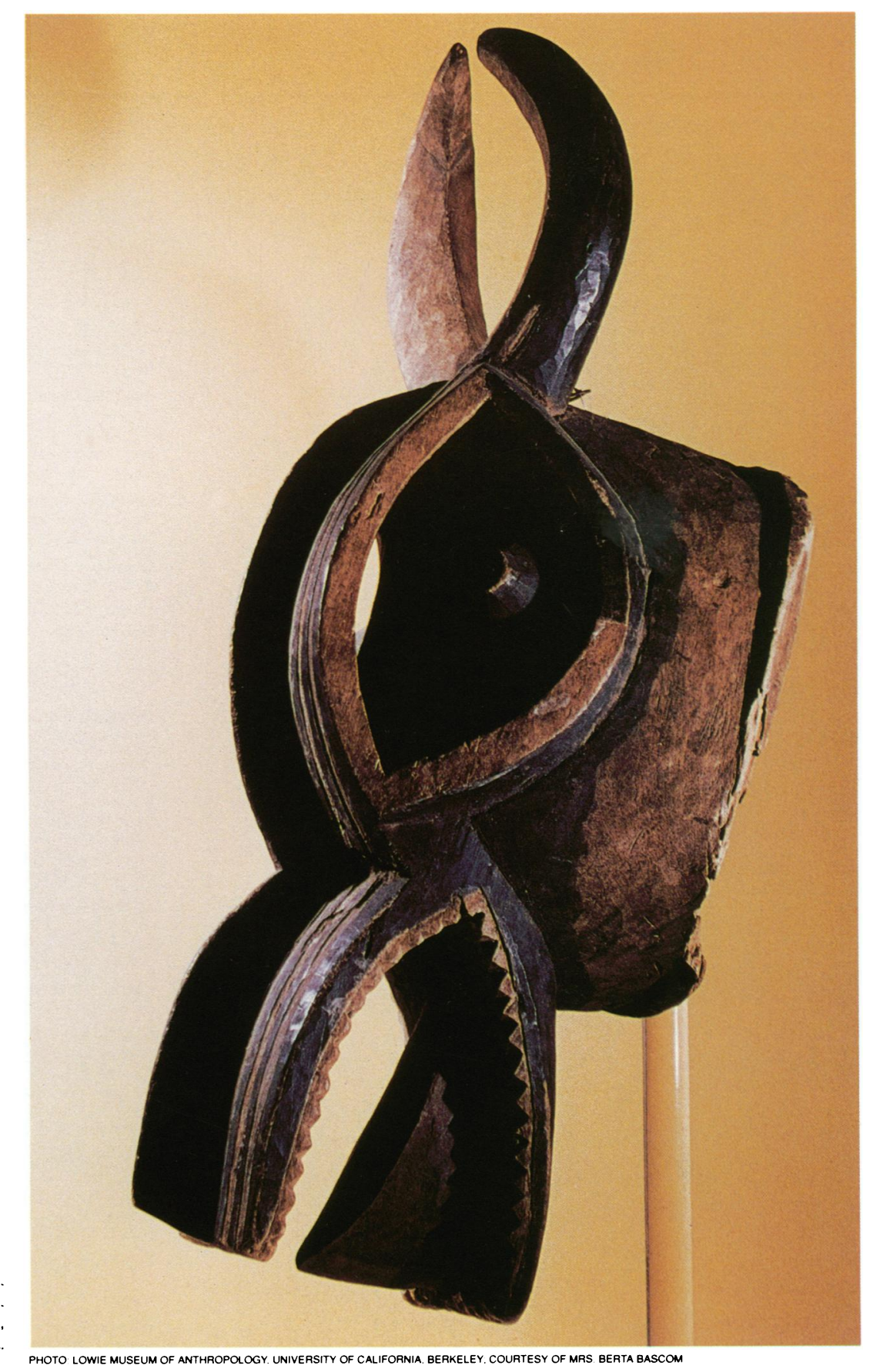


the patterns of conceptualization and function that characterized this kind of mask. In the process Adams suggested that many aspects of these patterns could not be explained solely by independent invention and parallel development. She concluded that the masks and much of their functional context may have originated in the area of the Dandai mask used by the Bandi (Gbande) in modern Liberia, and diffused along the savanna and the coast.

Robert Farris Thompson has also considered horizontal mask forms, with emphasis on their dramatic and pivotal supernatural ramifications (1974:14252). Roy Sieber has long been interested in them, as two of his publications (1961, 1974) and his classroom "chalk talks" indicate. And I have considered several Mande versions in some detail, describ-
4. A CHAMBA MASK IN PERFORMANCE. DONGA, NORTHERN NIGERIA, JANUARY 1965. ARNOLD RUBIN ARCHIVES FOWLER MUSEUM OF CULTURAL HISTORY, UCLA

ing them as powerful mediating metaphors and sources of actions linking the forces of nature and civilization (McNaughton 1979). But in the quarter century that has elapsed since Monni Adams's thesis, no one has explored the historical possibilities that horizontal masks may offer.

\section{The Map}

Many West African peoples use horizontal masks. Better-known examples include the Baga, Bamana, Banyang, Chamba (Fig. 4), Goemai (Fig. 6), Ijo,

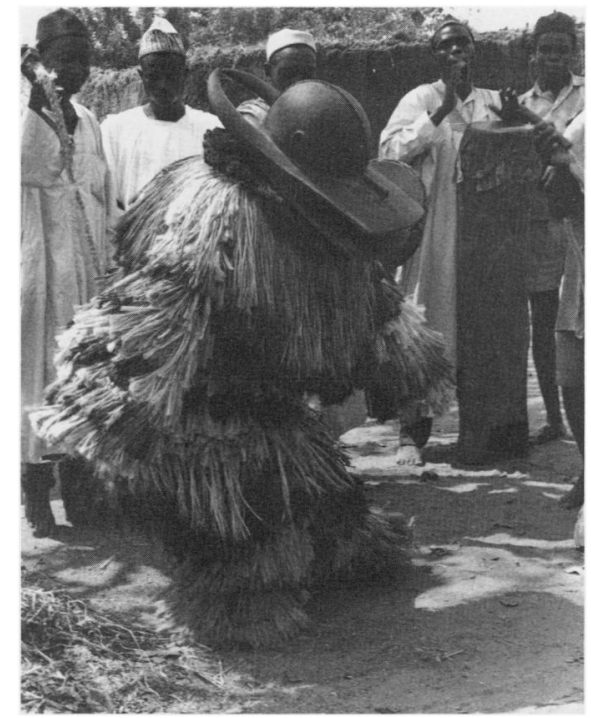

PHOTO- ARNOL RUBIN
Igbo, northcentral Kwa (Niger-Congo), E. "Locust" mask.

Cole \& Aniakor 1984:118, fig. 220 Igbo, northcentral Kwa (Niger-Congo), E. Mgbedike ("Time of the brave") mask. Cole \& Aniakor 1984:114, 131, fig. 213; Wittmer \& Arnett 1978:figs. 68(?), 69(?) lgbo, northcentral Kwa (Niger-Congo), E. Ojionu mask.

Cole \& Aniakor 1984:132,134, fig 238 Igbo, northeastern Kwa (Niger-Congo), E Ogbodo Enyi masq

Weston 1984:153-59, figs. 214 ,

270-75, pl. 29

Igbo, Nri/Awka Kwa (Niger-Congo), E Oji Onu (Long Mouth) mask.

Jones 1984:142, fig. 48

Igbo, Ekkpahia Kwa (Niger-Congo), E Trowell 1964:pl. VIIID (from Liverpool Museum)

42 ljo (Central), Kwa (Niger-Congo), E Jones 1984:160, fig. 68

ljo (Central), Kwa (Niger-Congo), E. Owu masq., Utobo (hippopotamus) mask Jones 1984:167, fig. 74 Wittmer \& Arnett 1978:figs. 89, 90

43 Issala, Voltaic (Niger-Congo), W Simma inst.

Cole \& Ross 1977:131

44 Jukun, Benue (Niger-Congo), $E$. Akuma inst., Akuma Wa'Unu mask. Rubin 1969, vol. 1:66-71; vol. 2, figs. 66-85 Jukun, Benue (Niger-Congo), E. Aku Maga inst., Aku Wa'Unu mask. Rubin 1969, vol. 1:59-66; vol. 2, figs. 30-40: Sieber 1974:fig. 15.

45 Kalabari ljo, Kwa (Niger-Congo), E. Owu mask. Jones 1988:fig. 8.

46 Kissi, West Atlantic (Niger-Congo), W. Poro inst., Landai (Dandai) mask. Celenko 1983:64-65, 67, nos. 49, 52? Kissi, West Atlantic (Niger-Congo), W Komo mask? Holas 1948:24-25.

47 Koko (Jakoko), Bantu (Niger-Congo), E. Sydow 1954:pl. 121A (citation from Adams 1963:37)

48 Kossi (near Douala, Bakosi), Bantu (Niger-Congo), $E$. Losango inst. Kecskési 1982:230

49 Kota (vertical mask), Bantu (Niger-Congo), E. Mungala inst. Adams 1963:38 Paulme 1962:118-19, pl. XXIII.

50 Koyara (Malinke). Mande (Niger-Congo), W. Do inst. Ravenhill, pers. com., 1990
51 Kru, Kwa (Niger-Congo), W. Holas 1980: unnumbered plate between pp. 256 and 257.

52 Kulango, Voltaic (Niger-Congo), W. Gbain inst

Bravmann 1974:119-46, pls. 38-56 Kulango (vertical mask, sometimes) Voltaic (Niger-Congo), W Bedu (Sakara, Sakrobundi) inst. Bravmann 1974:101-18, pls. 23-37

53 Kulere (Kaleri), Benue (Niger-Congo), E Kukom inst. Frank 1981:177-79, Abb. 104 Jos Museum, Nigeria (Sieber photo 1958).

54 Kutep, Benue (Niger-Congo), E. Sieber 1974:fig. 16.

55 Kwele (vertical mask). Bantu (NigerCongo, $\mathrm{E}$. Adams 1963:39; Cannes 1957:no. 193.

56 Landuma, West Atlantic (Niger-Congo), W. Simo inst., Banda mask. Van Geertruyen 1976:74-79.

57 Ligbi, Mande (Niger-Congo), W. Gbon inst.

Bravmann 1974:119-22;

Prouteaux 1918-19.

58 Loma (Toma), Mande (Niger-Congo), W. Poro inst., Landai (Dandai) mask. Celenko 1983:64-65, 67, nos. 49, 52? Gaisseau 1954:no. 49.

59 Mama, Benue (Niger-Congo), E. Mangam inst

Carroll 1966:ill.20; Roy 1979:60: Sieber 1974:fig. 14

60 Mambila, Benue (Niger-Congo), E Suah Dua, Suah Bvur, and Suah Buah masks. Sieber 1974:fig. 26 Schwartz n.d.: 15-17; Thompson 1974:143, pls. 182, 183; Tong 1967:pls. 13-16.

61 Manja, Adamawa-Eastern (NigerCongo). $\mathrm{E}$ Vergiat 1951:pl. XIII.

62 Mende, Mande (Niger-Congo), W Poro inst., Landai (Dandai) mask. Celenko 1983:64.

63 Montol, Chadic (Afro-Asiatic), E. Gugwom mask Sieber 1961:12, figs. 9. 31 Wittmer \& Arnett 1978:figs. 217, 219

64 Mossi, Voltaic (Niger-Congo), W. Roy 1987:ills. 69, 70

Mossi, Voltaic (Niger-Congo). W. Roy $1987: 77$

Mossi, Voltaic (Niger-Congo), W Roy 1987:ills. 72, 74, 76: Skougstad 1978:fig. 2
65 Mumuye, Adamawa-Eastern (Niger-Congo), E. Vabo inst. Sieber 1974:fig. 18 Wittmer \& Arnett 1978:fig. 216

66 Nafana, Voltaic (Niger-Congo), W Gbain inst

Bravmann 1974:119-46. pls. 38-56 Nafana (vertical mask), Voltaic (Niger-Congo), W. Bedu (Sakara. Sakrobundi) inst. Bravmann 1974:101-18, pls. 23-37.

67 Nalu, West Atlantic (Niger-Congo). W Simo inst., Banda mask. Bastin 1985:no. 34; Galhano 1968:no. 23: Huet $1978: 25$, figs. $28-30$ : Leuzinger 1963:82, no. 37 Van Geertruyen 1976:74-79. Nalu, West Atlantic (Niger-Congo), W Numbe mask? Bastin 1985:no. 33; Galhano 1968:no. 21

68 Nome, Voltaic (Niger-Congo). W. Simma inst.

Bravmann 1974:55-58, pls. 5, 6 .

69 Numu, Mande (Niger-Congo). W Gbain inst Bravmann 1974:119-46. pls. 38-56.

70 Nuna (Gurunsi), Voltaic (Niger-Congo), W. Roy 1987: ills. 169, 181, 193. Nuna (Gurunsi), Voltaic (Niger-Congo). W. Roy 1987:ills. 183, 184

71 Nunuma (Gurunsi), Voltaic (Niger-Congo), W. Roy 1987 : ills. 168, 178, 179, 190-92. 194, 207, 209 Nunuma (Gurunsi), Voltaic
(Niger-Congo). W. Roy 1987: ills. 176, 177 Underwood 1964: pl. 29

72 Ogoni, Benue (Niger-Congo), E. Talbot 1923:opp. p. 82 (citation from Adams 1963).

73 Sara Mbaye, Nilo-Saharan, E Ndo inst? Koy mask Fortier 1958-60:82-85, figs. 1, 2.

74 Senufo, Voltaic (Niger-Congo), W Poro inst., Kponyungo, Kunugbaha. and Gbon masks. Glaze 1981:256-57, pls. 8, 17, 63, 64 85. color pl. 9. Senufo, Voltaic (Niger-Congo). W Nosolo mask Glaze 1981:258, pl. 57 Huet 1978:figs. 140-44.
75 Sherbro, West Atlantic (Niger-Congo), W Thoma inst. MacCormack 1980:ills. 1, 2

76 Tampolense, Voltaic (Niger-Congo). W. Simma inst Bravmann 1974:55-58, pls. 5, 6

77 Temne (Timne), West Atlantic (Niger-Congo). W. Rabenle (Katinka Maneke. Maneke) inst.. Aron Etoma mask Thomas 1916:147, and 12-13, 28. 36. 74. 78, 143, 146-49, 169, pl. V. Temne (Timne), West Atlantic (Niger-Congo), W. Rabenle (Katinka Maneke, Maneke) inst. Nemankera mask? Thomas 1916:148. pl. V.

78 Tusya, Voltaic (Niger-Congo). W Roy 1987:ills. 309-14.

79 Vagala, Voltaic (Niger-Congo), W. Simma inst. Bravmann 1974:55-58, pls. 5, 6

80 Wan, Mande (Niger-Congo). W Do inst.. Goli gle mask Ravenhill 1988:88-94, figs. 2. 3. 7.8

81 Wasaw?, Akan-Kwa (Niger-Congo). W Sieber 1989; pers. com., 1990: Secret Museum of Mankind.

82 Winiama (Gurunsi), Voltaic (Niger-Congo), W Roy 1987:ills. 201. 203? Winiama (Gurunsi), Voltaic (Niger-Congo). W Roy 1987:ill. 202.

83 Wuri (near Douala). Bantu (Niger-Congo). E. Ekongolo inst., Nyati mask. Adams 1963:37: Paulme 1962:110

84 Yoruba (helmet, horizontal?), Kwa (Niger-Congo). E. Egungun inst Celenko 1983:114-15, no. 102: Curnow, pers. com., 1990 Nasara. pers. com., 1990 Yoruba (horizontal?). Kwa (Niger-Congo). E. Gelede inst. Thompson 1974:pls. 250. 251 Drewal 1983:pls. 3, 6, 19-23, 135, 138 141, 142.

Yoruba (monumental horizontal). Kwa (Niger-Congo). E.

Carroll 1966:64-69, ill. 51:

Curnow 1989.

Yoruba, ljebu (ljo-like masks). Kwa (Niger-Congo). E. Ekine inst.. Agbo mask Carroll 1966:ill. 14 
Loma (Figs. 7, 20), Mama (Fig. 8), and Senufo (Figs. 1,9). But this is just the tip of a horizontal iceberg that involves groups unfamiliar to Westerners as well as many well-known groups whose horizontal masks remain a relatively wellkept secret.

The coastal Ijebu Yoruba are known for their horizontal masks (Drewal et al 1989:144-45), while the northern Yoruba are not. Yet Father Kevin Carroll documented a truly monumental version in the northern Yoruba town of Egosi, a highly stylized antelope almost 2.5 meters long (1966:64-69, 162, ill. 51). It was the Great Mask, Oluwa, of the Udi osan festival. Carroll noted that there were "a few other" similar masks in the area, although he considered the Oluwa mask to be rather unusual for the Yoruba. Farther north on the YorubaNupe border, Abu Nasara photographed a horizontal Egungun mask (Fig. 10) in 1987 from the Yoruba section of Share/Tsaragi (pers. com., 1990). It was out for a funeral and then joined the simultaneous festivities in progress for the installation of the Nupe Emir. ${ }^{1}$ As a Peace Corps volunteer in the early 1970s, Suzanne Blier observed a horizontal mask in the northern Yoruba town of Sabe, which danced in honor of citizens returning from pilgrimage to Mecca (pers. com., 1990).

A combination of photographs and oblique references suggests that hori-

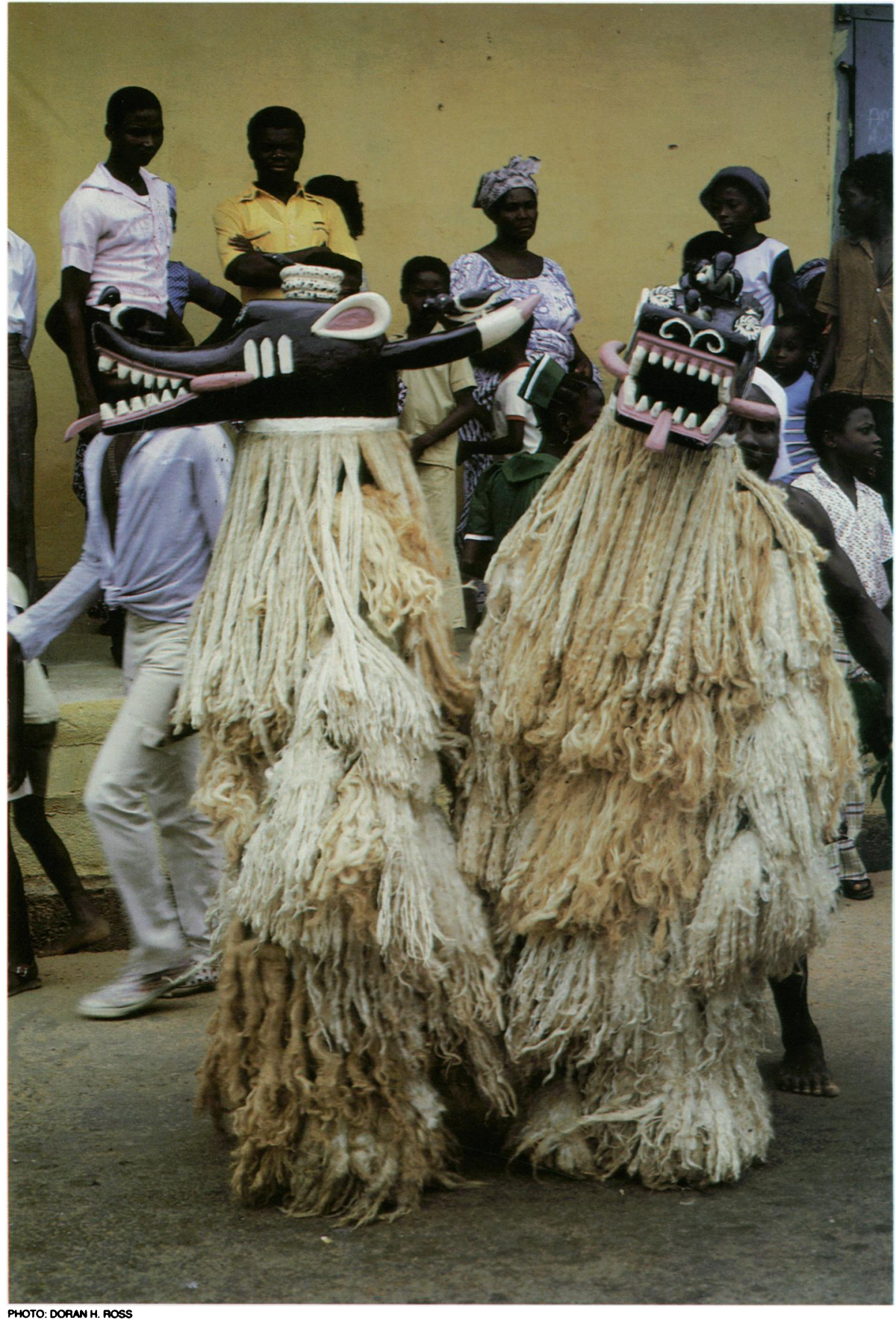

zontal masks have been used by the Fon (e.g., see Herskovits 1967, vol. 1:249; Le Herissé 1911:pl. XXI; Verger 1954:139). Blier corroborates them, noting that she was told such masks belonged to the Hevioso association, dedicated to the god of thunder, whose name means ram and buffalo (pers. com., 1990).

Southern (Akan) Ghana has generally seemed a lean art space for masking traditions. But Doran Ross (pers. com., 1991), Roy Sieber (pers. coms., 1989, 1990), Raymond Silverman (pers. com., 1990), and Monica Visonà (pers. com., 1990; forthcoming) have shown that horizontal masks are well known there (Fig. 5, Cover) and among the coastal Akan-related peoples of Côte d'Ivoire. In central Côte d'Ivoire, Philip Ravenhill (1988) has documented the horizontal masks of the Wan, a group poorly known to the West before his work. Yet it is that group who provided the betterknown Baule with their Goli horizontal masking tradition (Ravenhill, pers. com., 1990; Vogel 1977:124)(Fig. 2). This gave the Baule two horizontal mask institutions, the other (and older) being the more fearsome and secret Bonu Amuen (Fig. 11) (Vogel 1977:71-101).

I know of just two sources that document horizontal masks in the Chari and Ubangi River regions south of Lake Chad: J. Fortier on the Sara Mbaye (1958; 1958-60:figs. 1-2) and A. M. Vergiat on the Manja (1951:pl. XIII). This is not an area that has been well studied, especially by art historians, and one wonders how many more peoples there might be using similar masks.

The Maninka (Malinke) and Bamana (Bambara) are well known for their Komo association horizontal masks. But several Mande told me that the Maninka living west of the Niger River along the Mande plateau use especially, even fantastically, powerful horizontal masks in that association. I have no idea what they look like.

In short, preliminary exploration reveals a remarkably high incidence of horizontal mask occurrence across West and part of Central Africa. Nineteen of the nearly 80 ethnic groups who use horizontal masks have more than one version; that is, they use horizontal masks that are sufficiently differentiated in form or iconography that we might consider them individual types. The Bamana, for example, have Komo, Kono, and Nama association masks, all horizontal and all substantially distinct from each other. The Baga have Banda and $N u m b e$ masks. It is arbitrary to decide now what constitutes a separate 


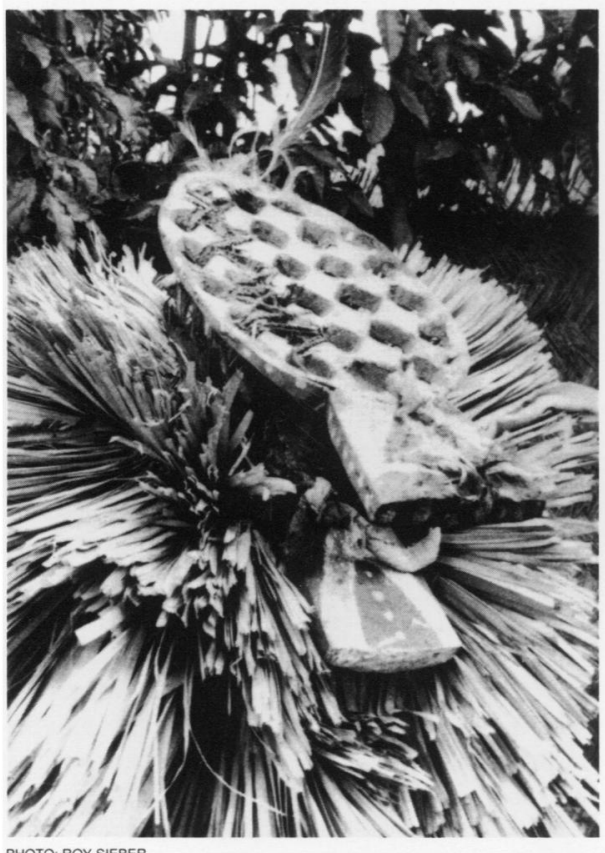

3. MASK, MAMA, NIGERIA. WOOD, $54.6 \mathrm{~cm}$ COLLECTION OF TOBY AND BARRY HECHT.

type, but I am comfortable saying there are about 107 of them.

A remarkable aspect of these statistics is the number of ethnic and language affiliations involved. For many scholars, pronounced differences in language represent significant cultural differences, and that leads to an important point. While those differences remain significant in many ways, if history links these masks, then one may conclude that divisions of language and culture do not inhibit the commerce of ideas and forms very much. That evidence lends important support to the new perspectives scholars are using to view ethnicity.

Based on the sources I have found thus far, there appear to be eastern and western clusters of horizontal masks. The space between them may represent a lack of shared history. Or it may reflect more recent historical processes such as the turbulent Islamic movements that could be at least partially responsible for the area's apparent dearth of masking traditions in general.

But who to include on the map is not always entirely clear. Beyond the obvious problem that the map was built from sources too condensed in time and too restricted in space, there are other difficulties. The Kru and Grebo have
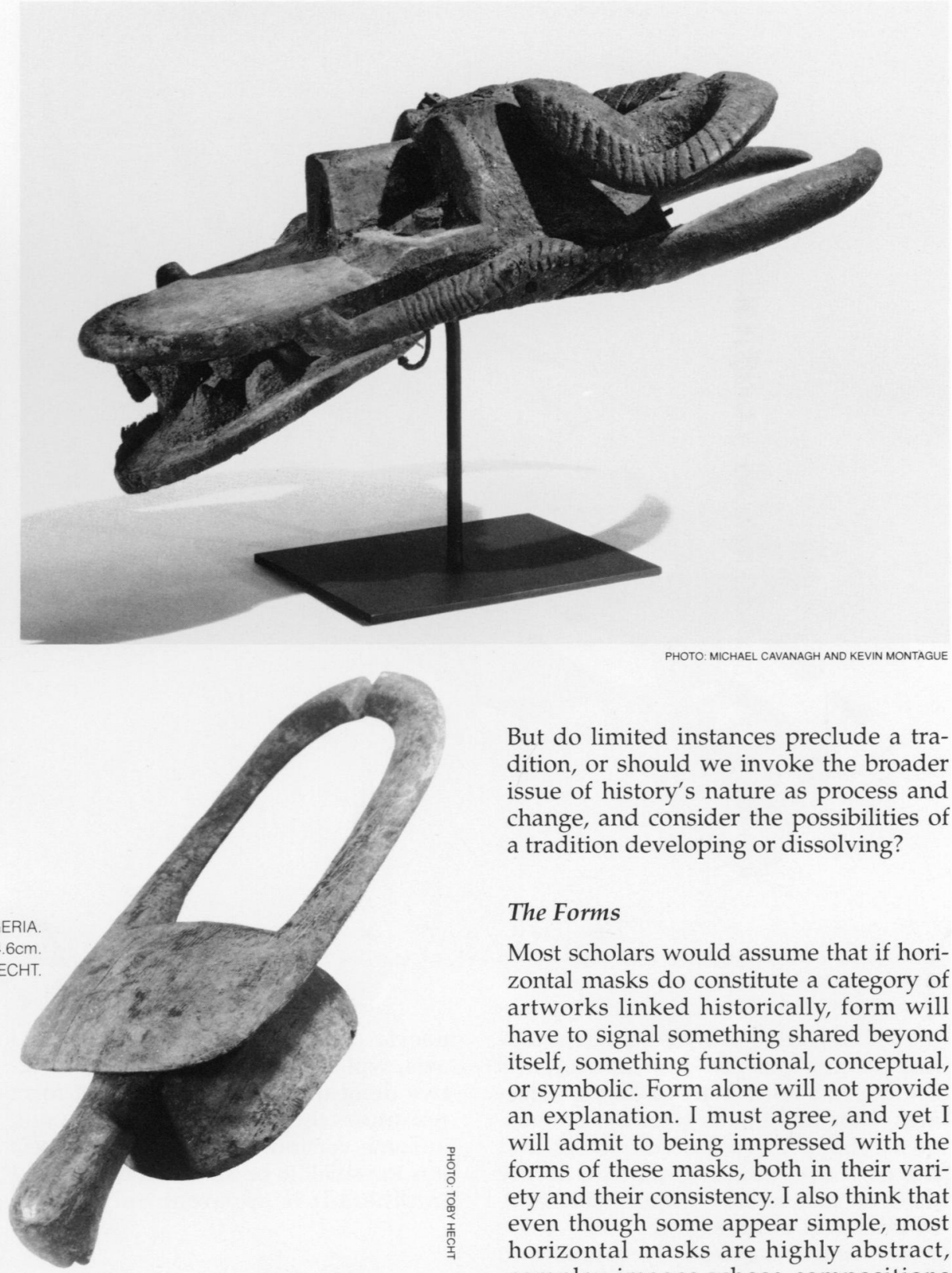

But do limited instances preclude a tradition, or should we invoke the broader issue of history's nature as process and change, and consider the possibilities of a tradition developing or dissolving?

\section{The Forms}

Most scholars would assume that if horizontal masks do constitute a category of artworks linked historically, form will have to signal something shared beyond itself, something functional, conceptual, or symbolic. Form alone will not provide an explanation. I must agree, and yet I will admit to being impressed with the forms of these masks, both in their variety and their consistency. I also think that even though some appear simple, most horizontal masks are highly abstract, complex images whose compositions may well harbor historical insights.

Adams (1963:1, 5-7), following Fraser masks that look as if they could be horizontal, and a photograph of one such mask shows it attached to a large plank worn horizontally atop a dancer's head (Holas 1980: between 256 and 257). ${ }^{2}$ Yet the eyeholes for dancers suggest these are face masks. Sieber notes that the Kru and Grebo masks he has examined show decided signs of having been worn as face masks, and he would consider the mask in the photo to be a face mask enlisted for an alternate kind of service (Sieber: pers. com., 1990). The interplay of form, use, and concept needs more examination.

Another question involves frequency of occurrence. Christine Kreamer illustrates a very unusual Ejagham (Ekoi) skin-covered headdress in the form of an antelope head (1986:59). Its horizontality and aggressive treatment of the mouth align it closely with horizontal masks.
(1962:53), characterizes these masks as "three-part masks... a blunt, elongated mouth, a cranium and pointed shapes which extend back from the head." Sieber identifies three different core elements: a helmet form, a mouth or snout projecting forward from it, and an "eye" cut out where the mouth joins the helmet, through which the mask wearer sees. In some headdress forms (Jukun, for example), that "eye" is present but not functional ( Sieber, pers. com., 1990).

The several characteristics I associate with horizontal masks are both structural and impressionistic, arrived at from my own perceptions. Some may be largely unrecognized by mask makers or users, who very likely would identify never thought, for example, to ask about horizontality or tripartite composition in others that I have not yet recognized. I 


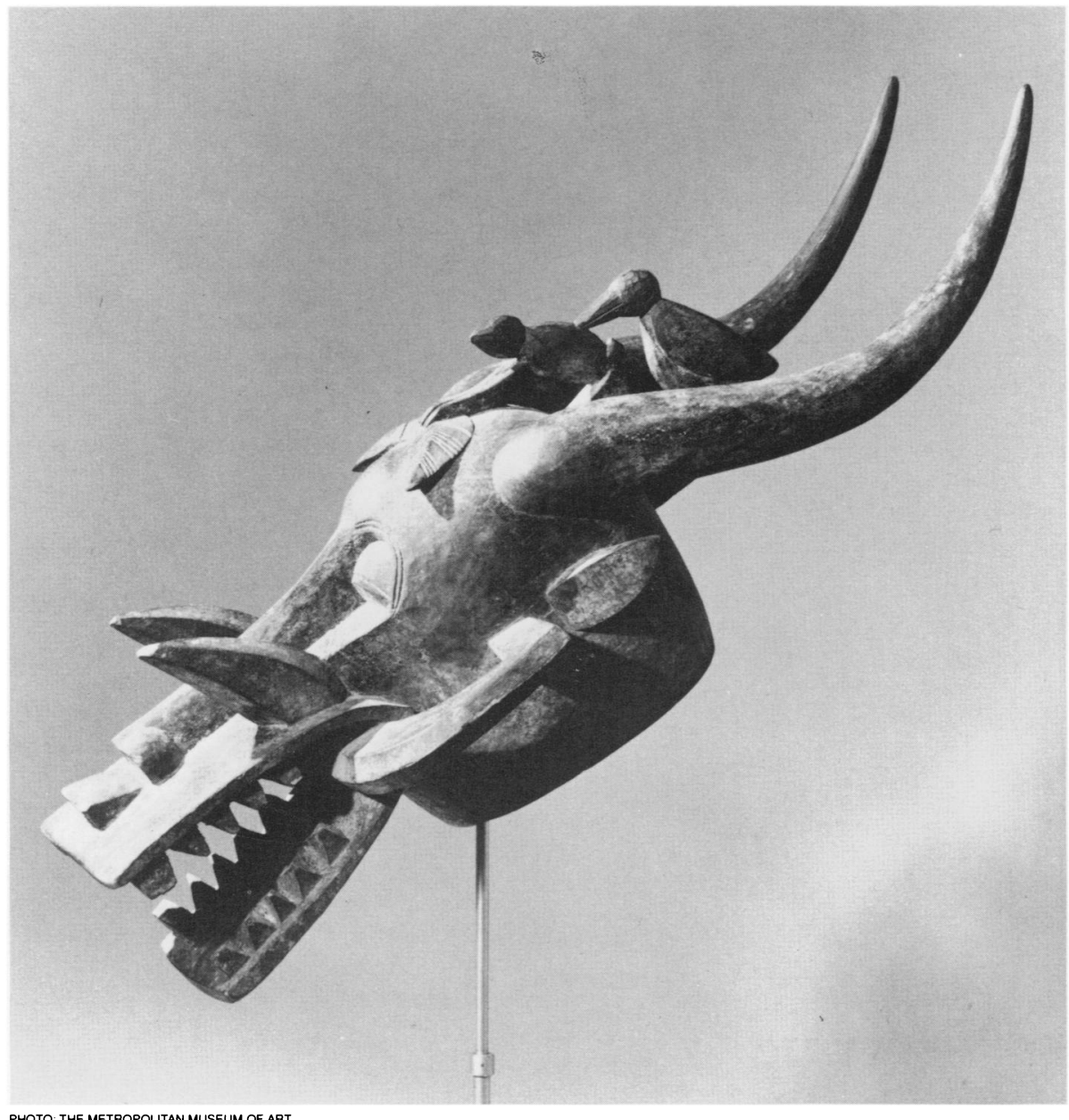

PHOTO: THE METROPOLITAN MUSEUM OF ART

the 1970s when I showed Mande sculptors photographs of Komo masks. Their comments tended to focus on the fierceness of the mouth, the quantity of attachments that expressed occult power, and the overall ambiguity that made the mask an adequately "obscure" (dibi) and, by extension, dangerous device.

It would be extremely valuable to know the indigenous characteristics of diagnostic importance, the fruits of privileged local knowledge. At the same time, characteristics that I discern from my own privileged position as an outsider with an overview are potentially of equal value. Ultimately I may need to adjust the list of qualities, dropping some of my own and adding others, such as fierceness, if they prove to be widely considered important. Acknowledging the characteristics' authors (outsider or insider) will be critical, as will be weighing these attributes against contextual evidence. There are no simple formulas for converting such information into historical understanding. Nevertheless, helpful insights are likely to emerge.

For now I see five key characteristics. First, of course, the masks are aligned nearly or wholly along a horizontal axis, which gives them a very distinctive demeanor. Second, a helmet form constitutes the central element, although in some versions (such as headdresses) it is too small to be an actual helmet and in others it is apparent only on the
9. MASK. SENUFO, CÓTE D'IVOIRE. WOOD, $94 \mathrm{~cm}$

THE METROPOLITAN MUSEUM OF ART, NEW YORK,

THE MICHAEL C. ROCKEFELLER MEMORIAL COLLECTION

BEQUEST OF NELSON A. ROCKEFELLER, 1979 (1979.206.71).

inside of the mask. Visible or not, it receives the dancer's head and generally serves as a rough compositional midpoint for the other elements. At least one variant (the Bamana Nama) is so small that it is carried in the hands and not worn at all, but the examples I have seen are still cut away underneath to create a helmet shape.

Third, a long mouth projects out from the front of the helmet. Generally it is large, even enormous, and sometimes it is full of dangerous-looking teeth. Fourth, projections, most frequently in the shape of horns, sweep back and often up from the rear of the helmet. Sometimes they are actual antelope horns. Sometimes they are simple abstract shapes.

Fifth, these structures very often give the effect of a tripartite composition in which the components blend to form an image, while still retaining their separate identities. An excellent example of this effect is the Kulere mask in Figure 12. That sense of the parts' independent existence is amplified by the fact that they are often rather straightforward, unadorned geometric forms (such as hemispheres and broad planes) connected with little superfluous articulation. It is largely this bare-bones tripartite aspect that establishes and characterizes the masks' extreme degree of abstraction. Indeed, like the Kutep mask in Figure 13, some are composed so abstractly that they very nearly lose their sense of animal vitality altogether and become simply abstract.

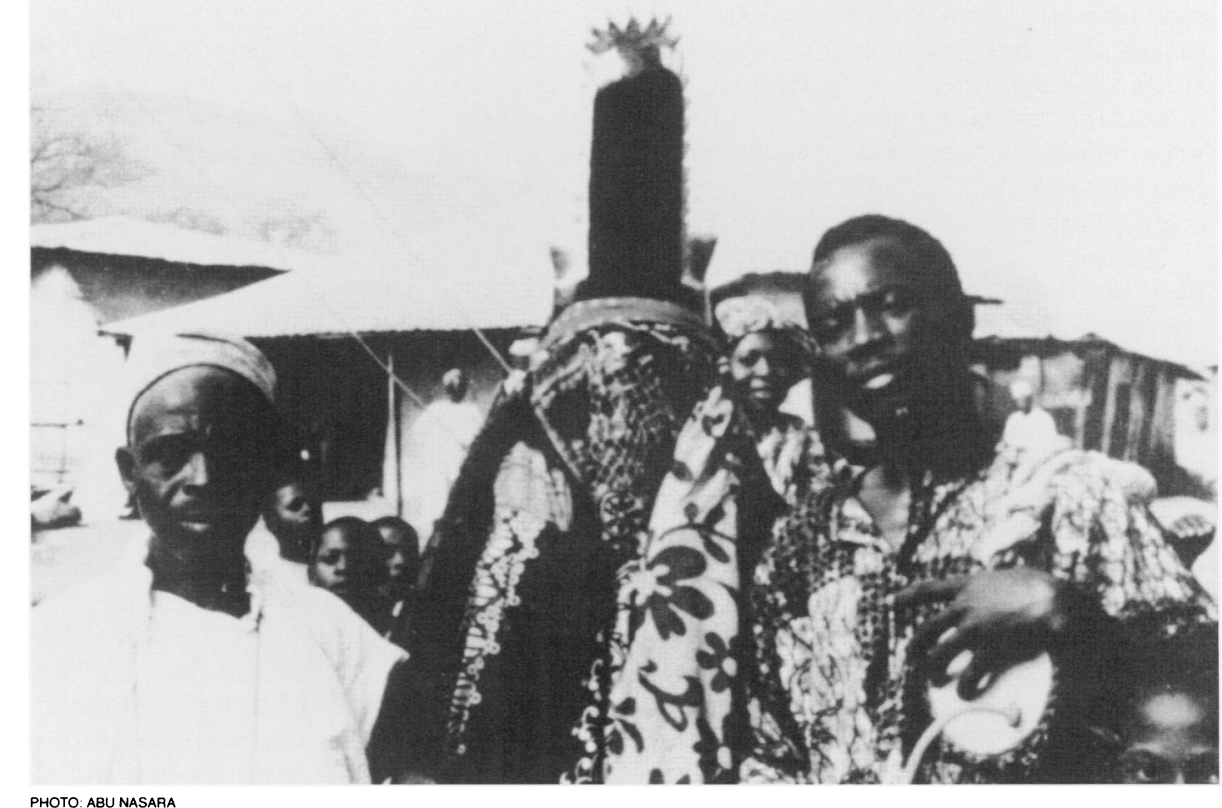


That abstraction can be appreciated better with reference to the things these masks suggest. People, snakes, antelopes, buffaloes, chameleons, elephants, hippopotami, crocodiles, hyenas, and birds have been identified as models for mask elements by informants from a broad spectrum of groups that use these masks. But generally these elements are combined so that the finished sculpture portrays no single creature, and often the resulting composite image appears to be important because that is a visual means to a conceptual end. Silverman was told in Ghana that these masks are composite images that portray supernatural power (pers. com., 1990). I was told in Mali that these masks look like horses but they portray secrecy and occult power; we cannot really know what they are. These statements seem consistent with the masks' appearance in most instances. Even the Idoma version illustrated here, with an obvious crocodile carved on top, still presents its own pronounced constellation of visually ambiguous elements (Fig. 14).

Thus, while some scholars may feel these horizontal masks appear simple, I would argue that they are complex, sophisticated compositions. The nature of their abstraction from natural referents, and the imagination that had to have been employed in the process, makes them so, and therein lies a sizable portion of their accomplishment. This

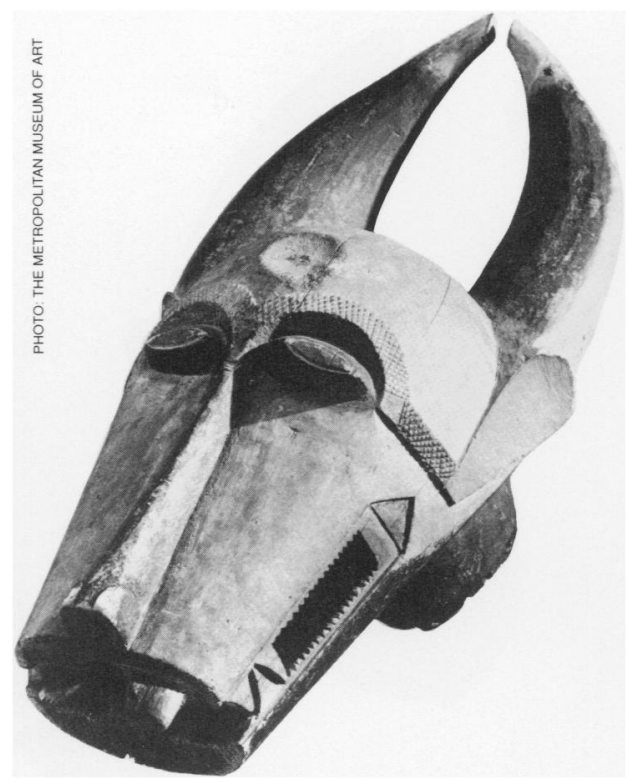

11. BONU AMUEN MASK. BAULE, CÔTE D'IVOIRE WOOD. $88.3 \mathrm{~cm}$

THE METROPOLITAN MUSEUM OF ART, NEW YORK

THE MICHAEL C. ROCKEFELLER MEMORIAL COLLECTION,

GIFT OF MR. AND MRS. BEN HELLER, 1958 (1978.412.341).

13. IKIKPO MASK. KUTEP, NIGERIA WOOD ORGANIC ADHESIVE MATERIAL, $53 \mathrm{~cm}$. INDIANA UNIVERSITY ART MUSEUM, BLOOMINGTON, GIFT OF BRYCE HOLCOMBE IN HONOR OF ROY SIEBER (81.74.2) visual complexity and sophistication are also what initially made me wonder if the masks could share a complex, common history.

The least abstract masks are in northern Nigeria and Cameroon, where Chamba, Mama, and Grasslands examples are said to picture bush buffaloes. The Grasslands versions are relatively literal (Fig. 15); the Chamba and Mama versions somewhat less so. I think it would be stretching it, however, to say the Chamba and Mama masks' tripartite appearance is prefigured in the structure of the actual animals' heads.

Grasslands masks, on the other hand, are not particularly tripartite, and that, coupled with their relative realism, makes them the least conforming mem-

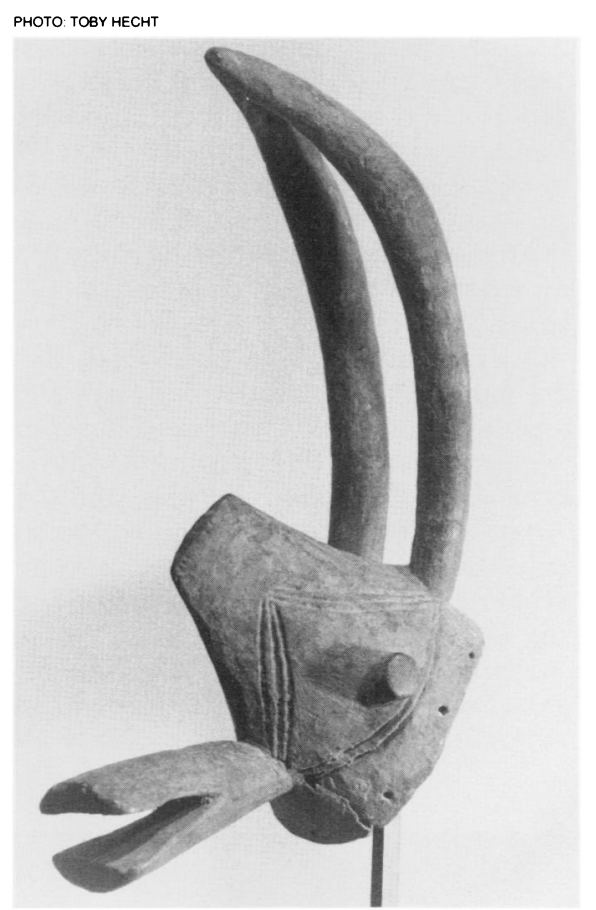

bers of the horizontal grouping. That brings up an important point. My five characteristics do not all occur in every example of the mask. Some Dogon (Fig. 16), Mbaye, Montol, and Senufo versions are made without horns, for example, while the Baga Banda masks and many masks from southern Nigeria employ somewhat different morphologies (Fig. 17). ${ }^{3}$ In fact, a few southern Nigerian versions such as the Abua example in Figure 18 seem to leave most of my criteria behind, leaving me wondering what exactly to do with them.

The contrast between the Dogon and Abua examples highlights a critical issue. I could decide to include in my deliberations only those masks that embody all five characteristics. Or I could try to reduce the number of characteristics until I reach the point where every mask has every one. To attempt either type of reduction, however, would be to seek a superficial simplicity (and a false security) that carries unpleasant baggage: namely, the notion that related African artworks must perpetually resemble each other to such a close degree that we also assert by extension that creativity and imagination are exercised infrequently and only in small doses.

I can readily imagine every one of the five characteristics being historically important, even though they may never have all been found in every mask. Consider these scenarios. If a group of people who have never before used horizontal masks experience one directly or encounter them through stories, they may decide to adopt such sculptures

12. MASK. KULERE (KALERI). NIGERIA WOOD, $48.3 \mathrm{~cm}$.

COLLECTION OF TOBY AND BARRY HECHT.

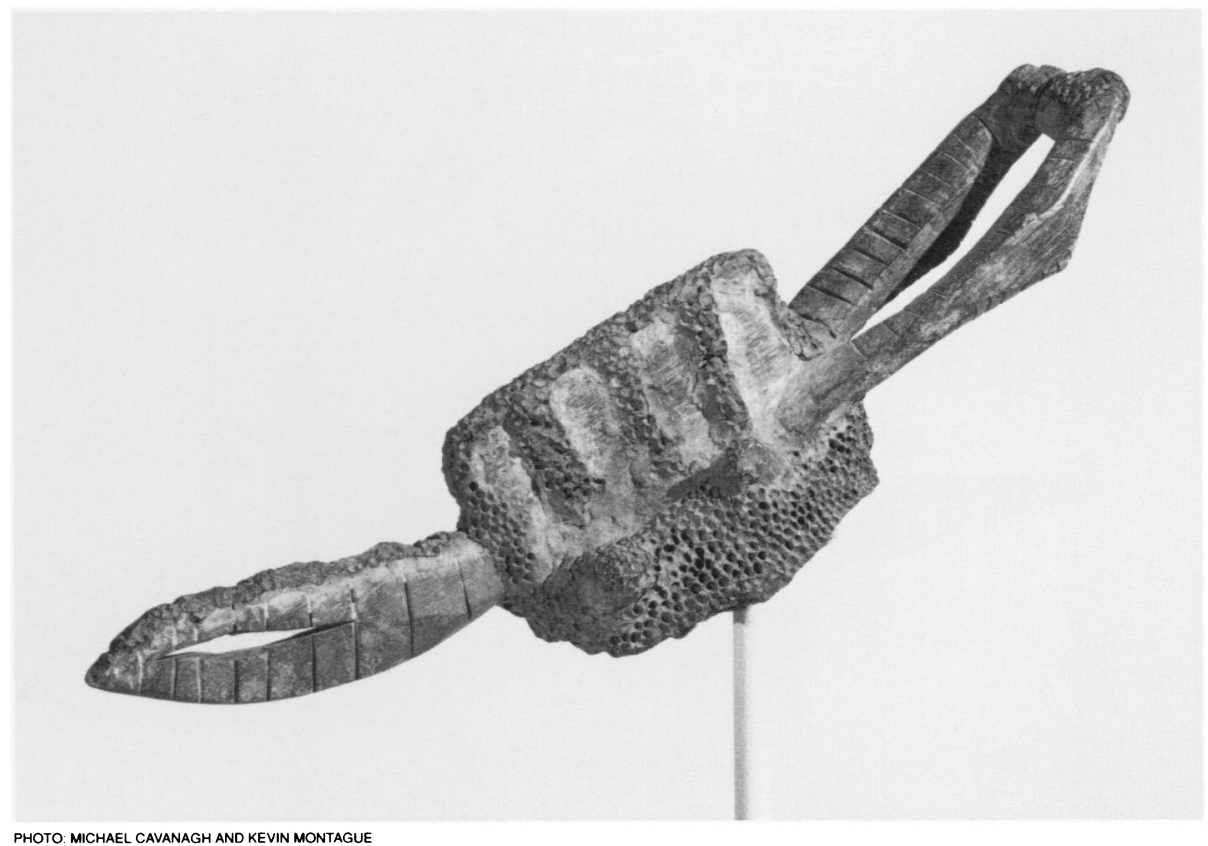


themselves. They might already possess a context for such masks, or they might find the context of the mask they have learned about to be appealing or useful. In fact they might only want the context (for example, a particular kind of cult that prevents illness and expunges malevolent sorcerers), into which they are happy to insert art they already possess or are willing to invent.

These scenarios are all possible. Judging from what little I have learned about the history of Komo masks and cult groups, coupled with my conversations with Komo leaders and members, they have all occurred in one way or another as that institution developed. Mary Jo Arnoldi's data (1983) on the puppetry traditions of the Bamana, Bozo, Somono, and Marka peoples around Segou in Mali suggest similar degrees of malleability, as do the uses to which Suzanne Blier, and Abu Nasara and Kathy Curnow, saw horizontal masks being put, as I noted earlier.

But to make a kind of sculpture their own, a group or assertive individuals within it might wish to drop mask horns, for example, or replace them with more abstract shapes that already occur in their artistic environment. Horns might well be fundamentally important to the masks of many groups, while still being superfluous for those of others. The history of a type of mask's transmission might therefore include the subtraction of certain characteristics, or the addition of others. That should not be surprising, however, when we consider African artists' proficiency at adaptation, a point I will return to later. Rather, it seems surprising that these five char- acteristics do cluster so consistently in the horizontal masks, and it is tempting to wonder if elements of history are not lodged in the inconsistencies. The problem, of course, is discovering a means of demonstrating that.

Though Cameroon buffalo masks are far less abstract than other horizontal masks, they are still helmet and horizontal in form, and some-like their cousins, Grasslands horizontal elephant masksare fairly abstract. Thus while they do not possess all five characteristics, they display enough of them to seem relevant to my study. And they seem much more closely aligned to their West African counterparts than to buffalo masks made 1,000 miles south in Zaire.

In the Kwango River region of Zaire, a cluster of peoples including the Yaka, Holo, Suku, Nkanu (Biebuyck 1985:184, 232, pls. 40, 84; Bourgeois 1984:125-28, 163; Cornet 1971:99-101; 1975:54; 1978: 110-11), and apparently the Zombo and Pende (Adams 1963:42; Félix 1987:209; de Sousberghe 1958:fig. 58; Sydow 1954: pl. 68A; Weeks 1914:opp. 222) all make bush buffalo masks within the context of an extensive tradition of animal depictions. ${ }^{4}$ While many examples of these masks appear vaguely horizontal, they are not tripartite or particularly abstract, and they generally conform to the combination face-helmet structure that is typical for the region. Further south, in Angola, the Ngangela seem to use an unusual initiation mask that is somewhat reminiscent of these Kwango River masks (Galhano 1968:no. 168).

Far to the east, near Lake Tanganyika, the Songye and the Tabwa are reported to have used bush buffalo

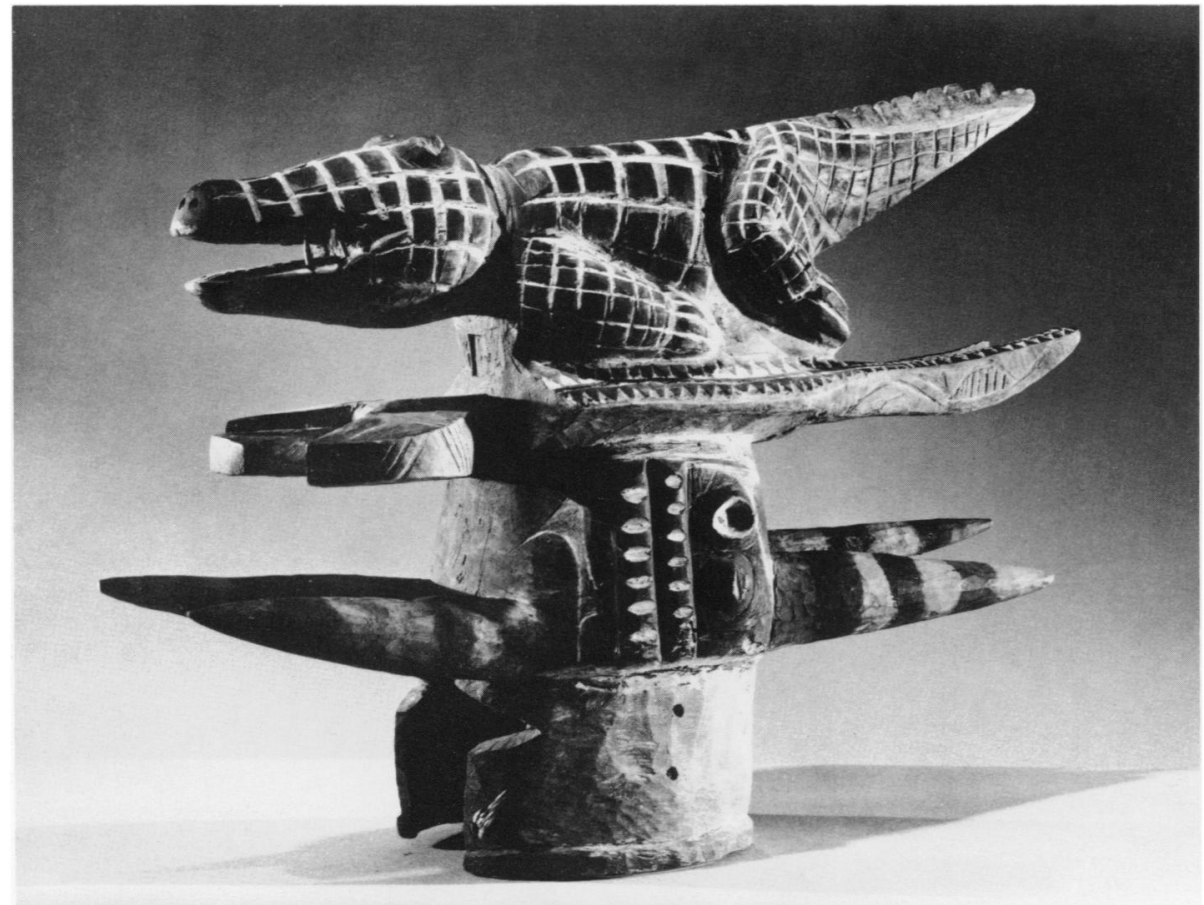

masks (Roberts \& Maurer 1985:82, 162-63, nos. 217-29), as are the nearby Bemba (Félix 1987:8-9). It is not at all clear whether the Songye versions were horizontal, and I know of only the above reference to them. But the Tabwa versions are not horizontal masks (Fig. 19). Although they project forward, with horns that sweep out and up from the sides, these are face masks with flanges at the rear for the attachment of raffia costumes. Like the Kwango River masks, they bear but modest resemblance to the horizontal masks of West Africa.

Thus, for now I would exclude these southern sculptures from my horizontal mask group. But what should I do with the West African Bissagos Islands bull and hippopotamus masks? They are the helmet type and would seem horizontal, except that their wearers dance on hands and knees, which gives them a vertical alignment (Gallois-Duquette 1983:105, figs. 69, 70). Besides, horizontality in itself is probably not enough to warrant inclusion in the group. After all, some Yoruba Gelede (Drewal \& Drewal 1983:ills. 3, 6, 19-23, 135, 138, 141, 142) and an occasional Egungun helmet mask (Celenko 1983:no. 102) can possess a little horizontality, sometimes in association with animal imagery.

In addition to the basic features shared by horizontal masks, it is easy to

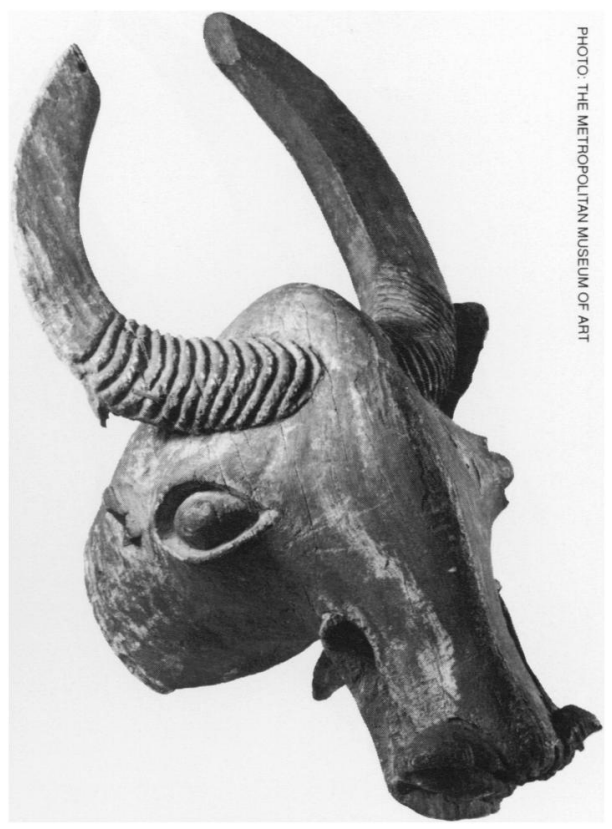

15. BUFFALO MASK. BAMILEKE (BANDJOUN), CAMEROON WOOD, $71.1 \mathrm{~cm}$

THE METROPOLITAN MUSEUM OF ART, NEW YORK GIFT OF NOBLE ENDICOTT, M.D., 1980 (1980.557)

14. CROCODILE HEADDRESS. IDOMA, NIGERIA WOOD, PAINT; $67.3 \mathrm{~cm}$

THE METROPOLITAN MUSEUM OF ART, NEW YORK, THE MICHAEL C. ROCKEFELLER MEMORIAL COLLECTION, GIFT OF MR. AND MRS. RAYMOND WIELGUS, 1962 (1978.412.462) 
identify regional partialities toward other characteristics. Projections upward along the masks' top surfaces occur widely in the western part of the range, among the Mande-related groups and the Baga, Senufo, and others. They also occur in southern Nigeria among the Ijo, for example, and the Cross River Banyang. Most Voltaic groups favor surfaces embellished with geometric patterns, as do the Baga farther west. Sacrificial matter, often in heavy accumulations, coats surfaces of Manderelated masks as well as Basinjom masks of the Banyang people.

Variation leads to formal gray zones that challenge masks' membership in this horizontal category I am contemplating. Simma association masks used by Vagala, Tampolense, Nome, Batige, and Issala peoples in northwest Ghana are conceived as broad, flat planes flowing out of bush cow horns (Cole \& Ross 1977:131, 133, fig. 289), sometimes with geometric shapes and even abstract bird beaks emerging from their centers (Bravmann 1974:57, figs. 5, 6). In both areas these sculptures' undersides display very shallow versions of helmet shapes, making them more headdress than mask.

Variation in another direction leads to horizontal masks with nearly spherical helmet portions. In central Nigeria Sieber photographed an Igala version with a wonderful horizontal cylinder in the background (1961:fig. 1) (Fig. 21). Northcote Thomas illustrates another version some 1,400 miles away, in Sierra Leone (1916:146-50, pl. V). Carol P. MacCormack illustrates two Sherbro horizontal masks (1980:159), one shaped like an inflated balloon with a distended mouth, the other shaped like a miniature pup tent.

Adams notes an interesting problem with masks used by the Kota and Kwele in Gabon (1963:38-39, figs. 73, 74). They resemble horizontal masks in structure but they are worn vertically. A similar problem can be associated with the masks of the Nafana, Degha, and $\mathrm{Ku}$ lango around the Bondoukou area of Côte d'Ivoire and western Ghana (Bravmann 1974:101-18; Pelrine 1988: 36-37; Williams 1968). They are very flat and often include large horns like the Simma masks mentioned above, but may be worn vertically.

Zoë Strother notes the opposite kind of problem. She found eastern Pende Kiwoyo masks and similar western Pende Giwoyo masks to be carved as if they were face masks with long extensions projecting from the chin (pers. com., 1990). But they are worn pushed up and back on the head so that they ride horizontally on top of it.

Formal (and geographical) middle ground is occupied by Voltaic peoples of Burkina Faso. Here tripartite structure

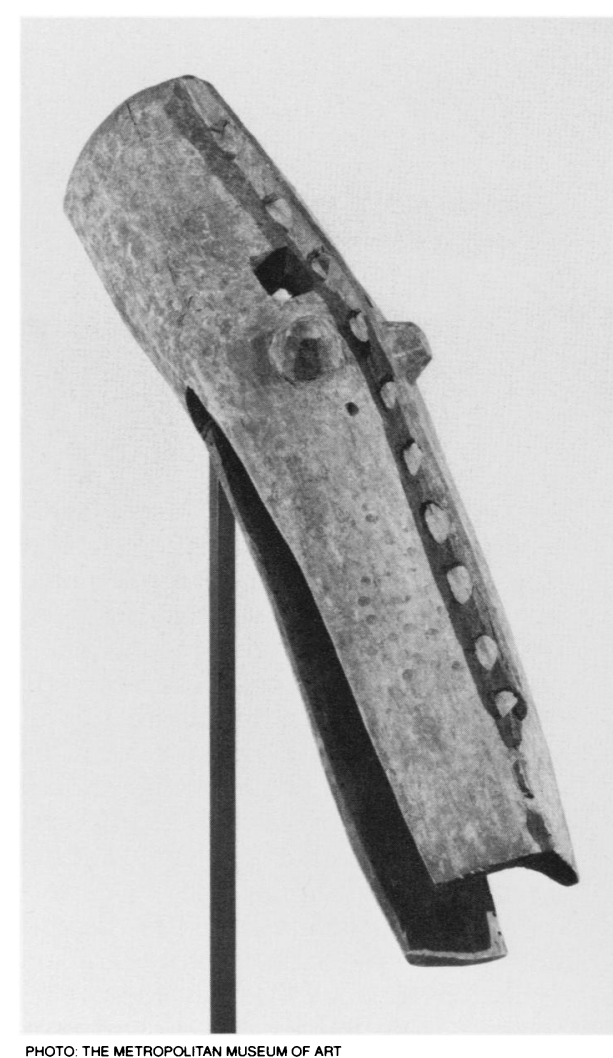

16. CROCODILE MASK. DOGON, MALI. WOOD. $96.5 \mathrm{~cm}$.

THE METROPOLITAN MUSEUM OF ART, NEW YORK GIFT OF LESTER WUNDERMAN, 1977 (1977.394.38)

17. MASK. IJO, NIGERIA WOOD, $96.5 \mathrm{~cm}$. COLLECTION OF TOBY AND BARRY HECHT.

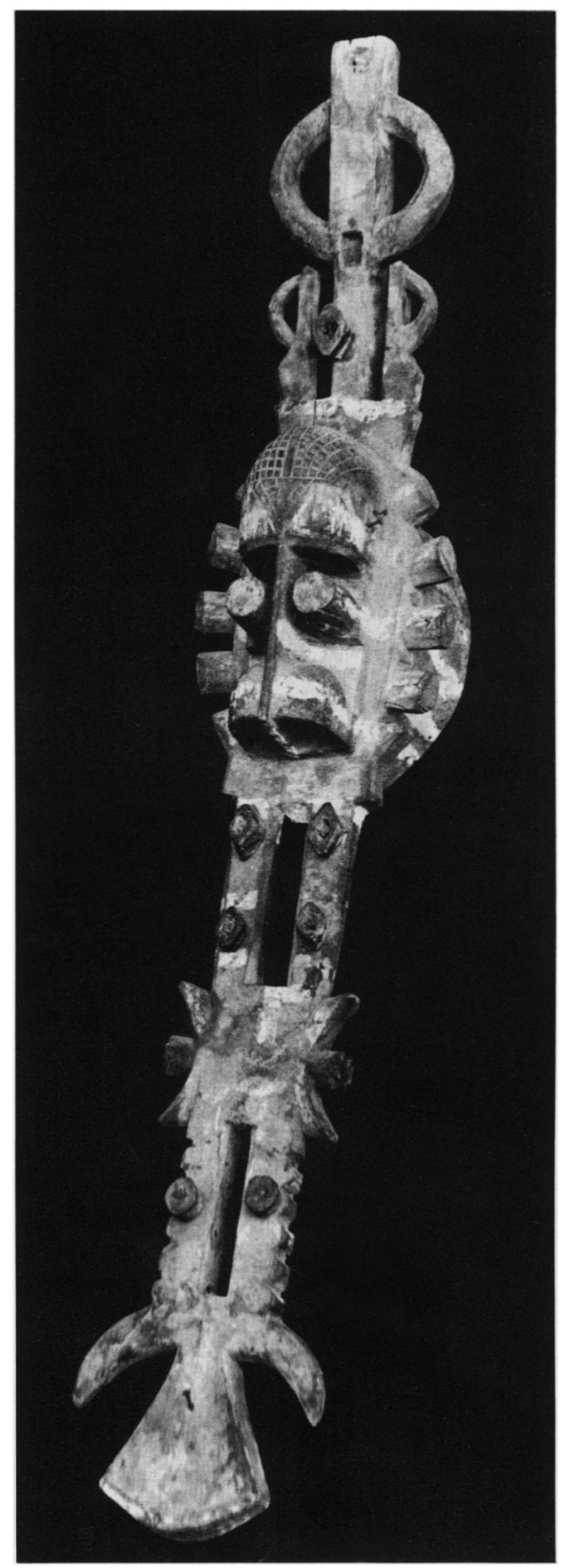

PHOTO: TOBY HECHT independent invention. If, however, it is the result of complex, lengthy patterns of interaction between cultures, then gaining an understanding of that history and the motivations that explain it would be most valuable. I think a great many scholars are predisposed to consider interaction on so large a scale in Africa unlikely. But we must remember that history is a process involving a multitude of motivations, agents, and activities by which people may obtain objects, institutions, and points of view from other people hundreds or thousands of miles away without ever having encountered them directly. In that light the visual similarities in horizontal masks might indeed be seen as possible representations of complex historical developments involving different peoples at different times and including an elaborate assortment of social and spiritual dimensions.

It is possible to suggest a general hypothesis for the spread of these masks. In Open Frontiers (1973) René Bravmann identifies the essence of the hypothesis: the pronounced mobility of art. In Patterns of Intention Michael Baxandall 


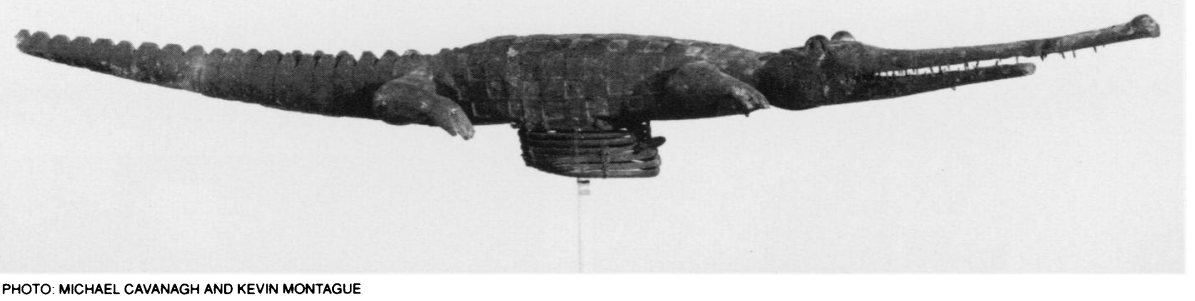

provides a critical element by suggesting how creative the process of artistic borrowing can be (1985:58-62). Tonye Erekosima and Joanne Eicher explore a specific African instance of "borrowing" and demonstrate several ways that adopted objects are transformed so that in effect they are created anew by their adopters (1981:48-51). Combining these ideas, I suggest that adoption and adaptation have often typified the responses of African artists and audiences to the arts of near or distant neighbors, and that the opportunistic transformation of other peoples' traditions is an essence of creativity and art history in Africa, as in many other areas of the world.

On an intercontinental scale, Arnold Rubin often referred in his class lectures to the results of these processes of transformation. In 1968, discussing the brass crucifixes made in the lower Zaire River basin, he emphasized the frameworks of function and symbolism that constituted the "Africanization" of such imagery. Paula Ben-Amos in her "Pidgin Languages and Tourist Art" (1977) and Kathy Curnow in "The Afro-Portuguese Ivories: Classification and Stylistic Analysis of a Hybrid Art Form" (1983) discuss these processes in reverse, providing insights into the ways African artists have adjusted their forms and images to suit foreigners.

These processes are worth dwelling on for a moment, because they have a much broader application than simply for art. Entrepreneurship and creativity are important aspects of the dynamic flow of African history. Research is beginning to show quite clearly that in the development of trade, the manipulation of technologies, the proliferation of religious institutions, the establishment of states and empires, and the rejuvenation of ideologies and practices, innovative strategies have been used frequently to create new social realities (e.g., see Barnes 1986, Harms 1987, Roberts 1987). Evidence is accumulating that art forms have sometimes been instrumental in these creations. ${ }^{5}$

There are problems associated with this hypothesis. One is how to demonstrate the presence in African art of an entrepreneurial orientation. More often than not, research in African art has focused on the search for norms, which tend to mask individual enterprise. Most often, too, creativity has been devalued by research perspectives that arbitrarily insist on Africa's conservatism and adherence to old forms. This means that decades of opportunity for the accumulation of relevant data have been lost, and arguments in favor of either individual enterprise or creativity as important features of African cultures must start at a pronounced disadvantage.

Another problem involves the present view of research that frowns on analytical criteria devised by researchers instead of by the art makers and users. For example, how many Yoruba or Pende think in terms of "helmet masks" or "face masks"? Obviously I am treating horizontal masks as a category, and if I persist in this research I will want to establish local criteria for doing so. I will also have to distinguish between those criteria and my own, and provide a rationale whenever I use mine.

\section{Contexts as Sources for Historical Explanations}

If enough data point toward a linked history for horizontal masks, and if my hypothesis provides a serviceable general rationale, then we will need to find a specific set of social or artistic forces that can provide an explanation for that history. We might look for a pattern in the uses to which these masks have been put and the meanings their users have given them. But here too we face problems, the most obvious being the limited data that are available, especially for precolonial periods. Another difficulty emerges from the hypothesis itself. Since it asserts creativity and transformation in adaptation, we should expect a variety of meanings and uses. And, on the basis of my preliminary examination of the literature, that is exactly what we get. But how can we use that to illuminate or verify a shared history?

A very general survey of the institutions that employ these masks helps illuminate the problem. ${ }^{6}$ They are cults or initiation associations that serve their communities overtly and covertly as prominent agents of established religious beliefs and practices. They play
18. CROCODILE HEADDRESS. ABUA, NIGERIA WOOD BAMBOO $221 \mathrm{~cm}$ INDIANA UNIVERSITY ART MUSEUM BLOOMINGTON (72.116.2)

important social, political, economic, and educational roles involving the reduction of social and spiritual friction, the transmission of values, and the enactment of punishments for those who violate them. These associations are frequently considered secret, and they harbor much special esoteric and practical information. But they may be joined by a huge proportion of the population-in some instances, for example, all adult men are by definition initiated. In several areas membership cuts across many special-interest groups, from family to professional categories and even ethnic affiliation. In other areas the cults are for specific extended families.

The functions of these cults also vary. Generally they include some combination of curing diseases, ending misfortune or protecting against it, helping insure a successful harvest, creating general well-being or success in specific activities, assisting with problems of human infertility, protecting against antisocial sorcery, assisting people under that kind of attack and punishing the attackers, carrying out divination, and protecting against the dangers of the wilderness (especially spirits). The cults accomplish these things through a combination of two sources of power: relationships with spiritual beings (such as ancestor spirits or wilderness spirits) and the supranatural energies that can be harnessed by experts in herbal science and ritual. Thus, the essence of the cults' social charter is that they use powers that the West calls supernatural to articulate the nature of the world from its occult underbelly.

The masks themselves perform at a great variety of cult events, which again vary from group to group. These events include the initiation of new association members, funerals of senior members or city leaders, agricultural ceremonies, chiefs' installations, and regularly scheduled association meetings during which horizontal masks may be involved in activities such as cleansing the town of malevolent spiritual forces or antisocial sorcerers, offering up prophylactic doses of occult energy, and performing soothsaying procedures. The masks may also be brought out of their special storage places and into either town or bush for regular ceremonies that imbue them with power-laden materials through acts of sacrifice. George Brooks observed that one Nalu variant of these masks is simply kept on a shrine at the edge of town, where it offers permanent protection (pers. com., 1988). 
Frederick Lamp notes that while most Guinean horizontal masks that are illustrated (such as Fig. 23) are labeled Landuma, Baga versions also serve as shrine sculptures (1986:66).

Most horizontal masks are stored in secret and sometimes sacred places. Often the priest-leaders keep them hidden away in trunks in their bedrooms. Often, too, they are housed in specially constructed shrines within town boundaries, but they may also be stored in the sacred forests where many of these cults undertake much of their business.

In other words, the contexts in which horizontal masks function and the specific collections of powers and tasks attributed to them are similar in nature and in their considerable variation to the contexts and functions of many other mask and figure types in sub-Saharan Africa. We are not simply looking at an art form that accompanied the spread of a particular kind of institution, although in some instances, as I will show in another article, something along those lines happened. Nor do I yet know a special functional context or particular set of ideas that would make a horizontal mask more likely to be used than other kinds of artistic expression, although these could emerge with additional research. This is a particularly troublesome dilemma. I would have appreciated finding functions, meanings, or settings unique to horizontal masks; the variety we instead encounter matches the assertions of my general hypothesis, and by that very fact makes proving a linked history difficult.

But if a helpful pattern of use has not emerged, another feature of the evidence could prove salutary. Horizontal masks are frequently described by their users as particularly powerful occult instruments. Carroll suggests this for a northern Yoruba horizontal mask (1966: 67-69). Anita Glaze suggests it for Senufo horizontal helmet masks (1981: 137-40). Sieber (pers. com., 1990) and Visonà (pers. com., 1990) heard such testimony in Ghana and coastal Côte d'Ivoire. I heard it in Mali. And Vogel describes it for the Baule (1977:71-72). In fact, Sieber and Visonà both were told that horizontal masks were "imported from the north" at least partly because they were so much more powerful than other masks, while Vogel learned that the Mande Wan, from whom the Baule borrowed their Goli masquerades, "are known among the Baule for their powerful fetishes and medicines" (1977:124).

This is not yet much to go on, and it is not without its.own problems. For example, one could not simply argue that horizontal masks are Africa's most powerful occult sculptures; that would be missing the point. An observable, relative consistency in the impressions of and attitudes about power in masks is what I have in mind, and if that were to be proven it would mean we had established a diagnostic distinctiveness not by category but by degree. The usefulness of that particular kind of distinction in the imagination of potential users might prove to be the entrée that could help propel horizontal masks across African landscapes.

\section{Power in Form}

In an essay to follow, I will survey enough literature to suggest that additional research is in order, because a preliminary glimpse of history shows that many of these masks are linked, and many more may well be. I want to conclude here, however, with another hypothesis, which applies to more than

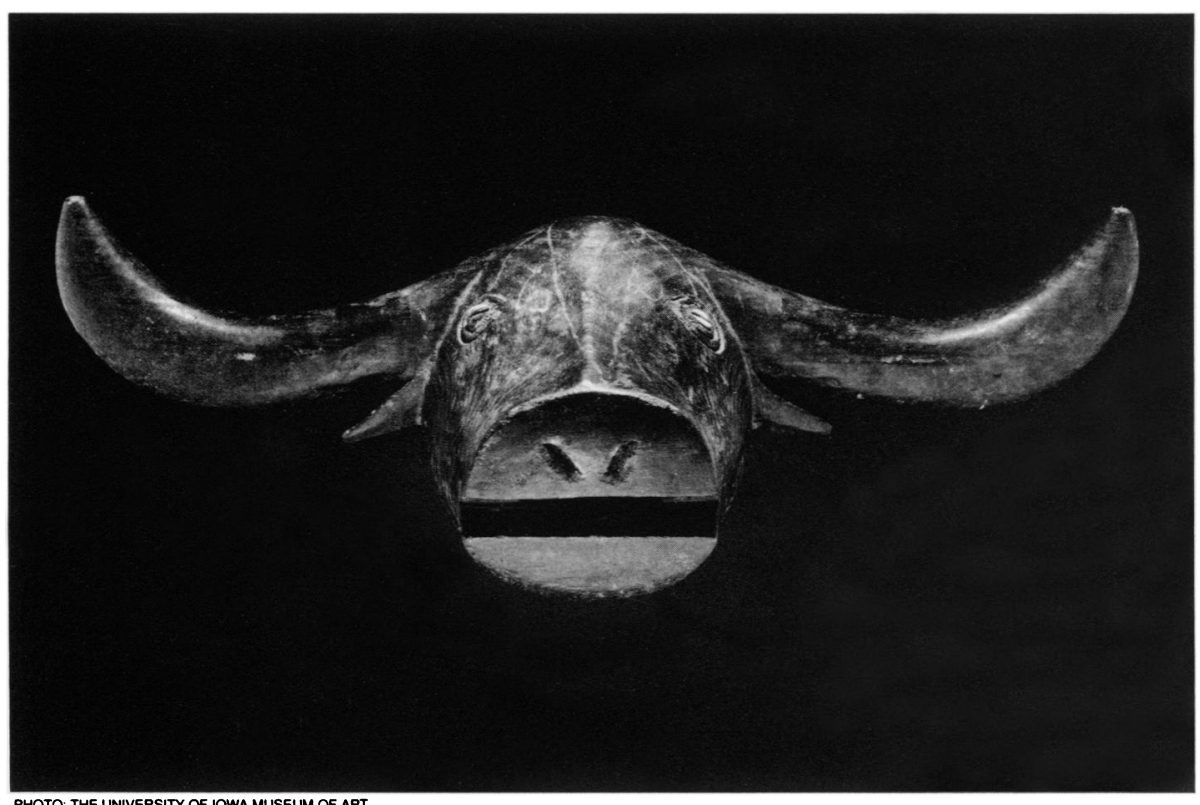

history but also pertains directly to my deliberations in this essay.

I became interested in the forms of these masks not simply for themselves, but for something I think people put in them. They are not passive, neutral, or insignificant. Because they are created frequently by artists of talent and intelligence, or because they are experienced frequently by viewers who are interested and capable of contemplation, many forms acquire a kind of power.

This power is not mystical or subliminal or unconscious-the mind writ elusively in objects. Nor does it spring from aesthetics in the narrow sense of formal judgment. Rather, it is a tangible, pliable quality generated from the way minds work (as we presently understand them), a kind of staying power that is manifest when a form captures the imagination of its makers or users. The best way to describe it is with reference to Nelson Goodman, the philosopher, and Thomas Kuhn, the historian of science.

Goodman has discussed at length the idea that there is no real world, but only realities that minds construct through symbolic processes (Goodman

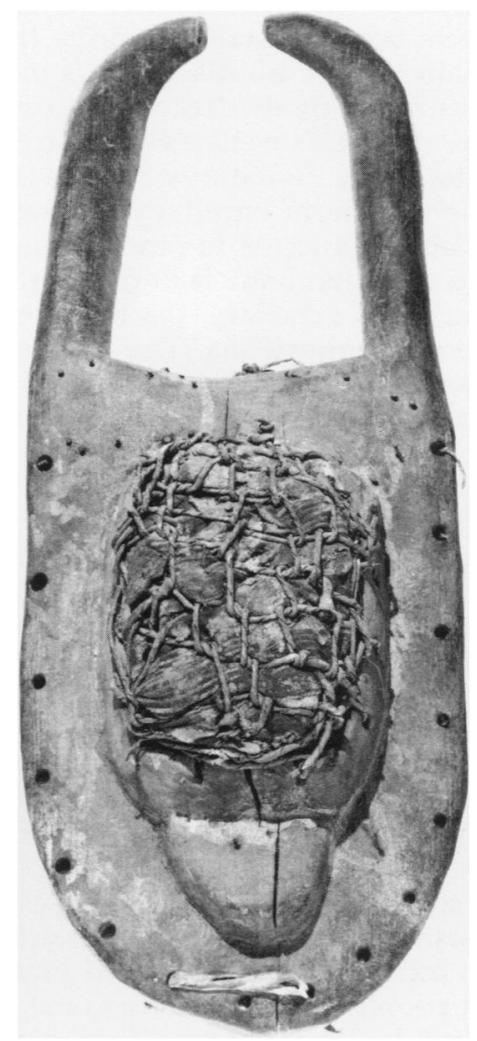

20. MASK. LOMA (TOMA), LIBERIA/GUINEA. WOOD. LEATHER, CLOTH, FIBER: $96.5 \mathrm{~cm}$. INDIANA UNIVERSITY ART MUSEUM BLOOMINGTON (63.238). 


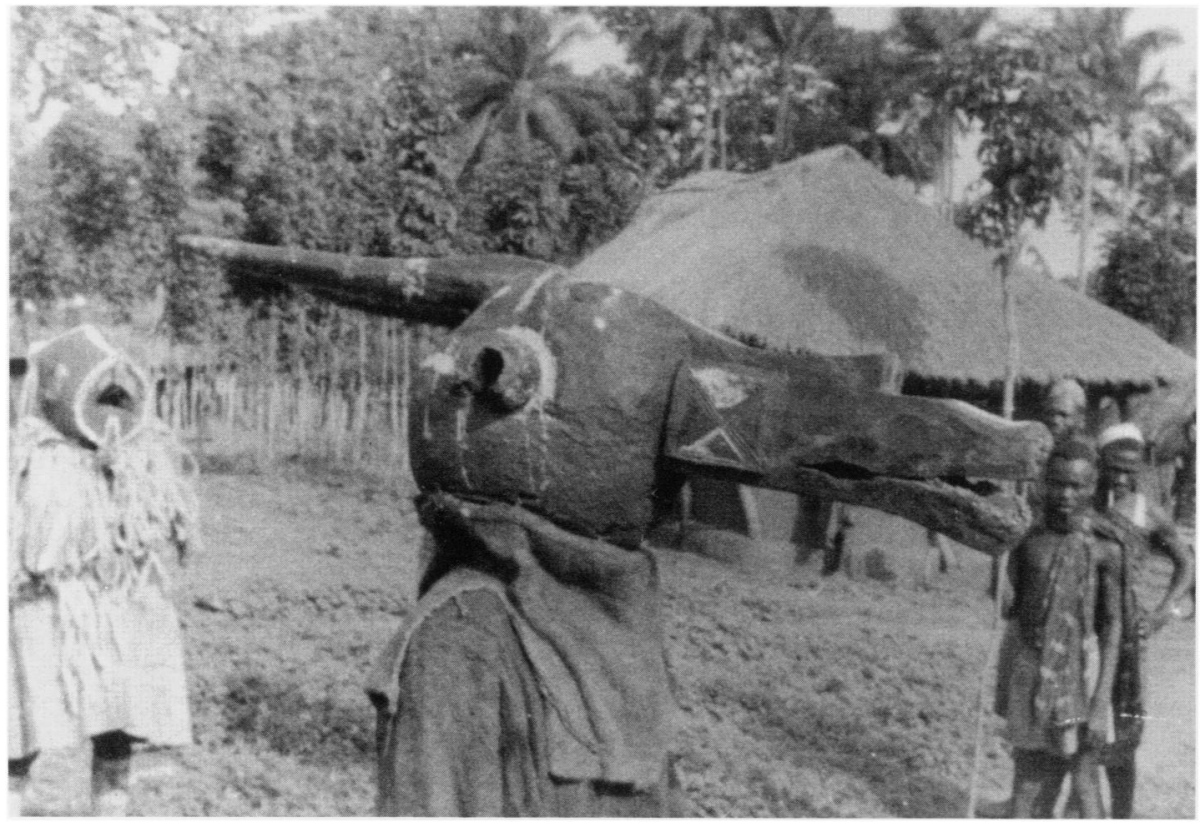

PHOTO: ROY SIEBER

1984; also Bruner 1986:93-105). We all receive these constructed realities, which become the basis for us to construct our own. Tzvetan Todorov on Mikhail Bakhtin says something very similar: "...there are no nameless objects nor any unused words. Intentionally or not, all discourse is in dialogue with prior discourses on the same subject, as well as with discourses yet to come..." (Todorov 1984:x). In the same way, form once created becomes instantly connected to other forms and to discourse about it and them. The broader its exposure, the more extensive its connections. The greater its impact on people's experiences, the more pronounced and observable its history. That impact is the template of its power.

The power becomes sizable when the form becomes established, a process we can liken to the history of scientific revolutions. Thomas Kuhn has shown that, in science, once a theory or collection of related theories (a perspective, or ideology) topples its predecessors, it acquires a sustaining power that causes it to endure until enough momentum builds up in new theories to start the process over again (Kuhn 1976). Like the forms (math) and ideas in physics, for example, the forms and ideas in art also accrue a kind of accepted presence that people invest in and become committed to. The history of art, no less than the history of science, suggests that this is true.?

In a sense this power in form is the form's memorableness, derived from the praxis of aesthetics as systems of thought in conjunction with the play of ideas as they join the experiences of people to the compositions of artworks. People perceive art according to their
21. TWO IGALA MASKS, ONE CALLED IKONYI ("BIG MOUTH"), IN THE FOREGROUND, AND THE OTHER HIS WIFE ODOMODO ("TOO BIG"). INYE, NORTHERN NIGERIA, MAY 1958.

cery, for example, and that users do not care how it looks. These positions have been modified and softened over the years, but they continue to influence our endeavors.

The term "aesthetics" can signal many things, from canons of taste and artistic skill to systems of critical contemplation that incorporate ideas from a broad spectrum of social processes. I think scholars have often construed aesthetics in the narrowest sense of formal judgments. In doing so we have split the personality of a potentially rich mental and social phenomenon, restricting its usefulness to us quite severely. We would have done better to heed Gombrich's insight:

\begin{abstract}
...writers on aesthetics have been at work so long telling us what art is not, they have been so anxious to rid art of any heteronomous values, that they have created a rather forbidding void in the centre. The synesthesia of values crystallized in our linguistic habits shows, I believe, that this void is artificial...in our living experience [aesthetic values] always find resonance in other areas of value.
\end{abstract}

(Gombrich 1978:15)

The point of this statement, written originally in 1952, is obvious but nevertheless neglected. We can parlay aesthetic analysis into deeper understandings of artworks and their cultural settings, a fact Gombrich illuminates nicely in his 1978 article on visual metaphors of value.

There are not many studies of African aesthetics, perhaps partly because the prevailing attitude has made them seem fruitless. Yet work by Kate Ezra (1986), Philip Ravenhill (1980), Robert Farris Thompson (1973), and Susan Vogel (1980), for example, demonstrates that aesthetics indeed exist in at least some African societies, where they are construed quite broadly, in a Gombrichian sense. My own work on Bamana aesthetics (1979, 1988) also suggests that to study form is to study thought and social action, it being possible to separate the three only in the arbitrary atmosphere of scholarly analysis.

This brings another aspect of form's staying power into focus. As part of people's consciousness, form is subject to the action of two frames of human behavior that scholars have called the transactional self and the dialogical imagination. Both emphasize interactions, but slightly different kinds and in 
sessing unique personal histories that cause incoming information (the direct or indirect exchange of ideas) to be compounded in unique, individual ways, which results in society's being composed of multiple and often conflicting voices (see Holquist 1981: 259-422; Todorov 1984).

Form's complex involvement in history is summarized rather well in light of the transactional self and dialogical imagination approaches to behavior. When people respond to visual forms they bring the component of consensus implicit in a transactional model and the component of individualism implicit in a dialogical model to bear against each other. The struggle that results could lead anywhere and is totally contingent upon the situation in which the forms are encountered and the intellectual, psychological, and social circumstances of the individuals who encounter them. That is why art historical reconstructions are so difficult.

We have gradually begun to recognize the subtleties of human enterprise involved in the production and historical transmission of art forms. It is no longer sound scholarship to try to deduce common histories solely from shared forms. Yet form, as a kind of thought, remains a tool art historians should continue to learn how to use. It is as short sighted to expunge form from our considerations as it is to consider nothing else.

It remains entirely possible that no common history links all horizontal masks, or that I will not be able to find one. But if there is one, and if it can be discovered, then I would suggest that the power in form will have played a role in both the history and its discovery.

Notes, page 88
22. A NUNUMA BUSH BUFFALO MASK PERFORMS AT A FUNERAL

TISSÉ, BURKINA FASO, 198

23. MASK. LANDUMA, GUINEA. WOOD BRASS TACKS: $78.1 \mathrm{~cm}$. THE METROPOLITAN MUSEUM OF ART, NEW YORK THE MICHAEL C. ROCKEFELLER MEMORIAL COLLECTION, BEQUEST OF NELSON A. ROCKEFELLER, 1979 (1979.206.210)

slightly different ways. The former considers behavior from the perspective of shared mental structures. It conceives of transactions as "those dealings which are premised on a mutual sharing of assumptions and beliefs about how the world is, how mind works, what we are up to, and how communication should proceed" (Bruner 1986: 57). ${ }^{10}$ The latter considers behavior from the perspective of multiple points of view. It conceives of people as pos-

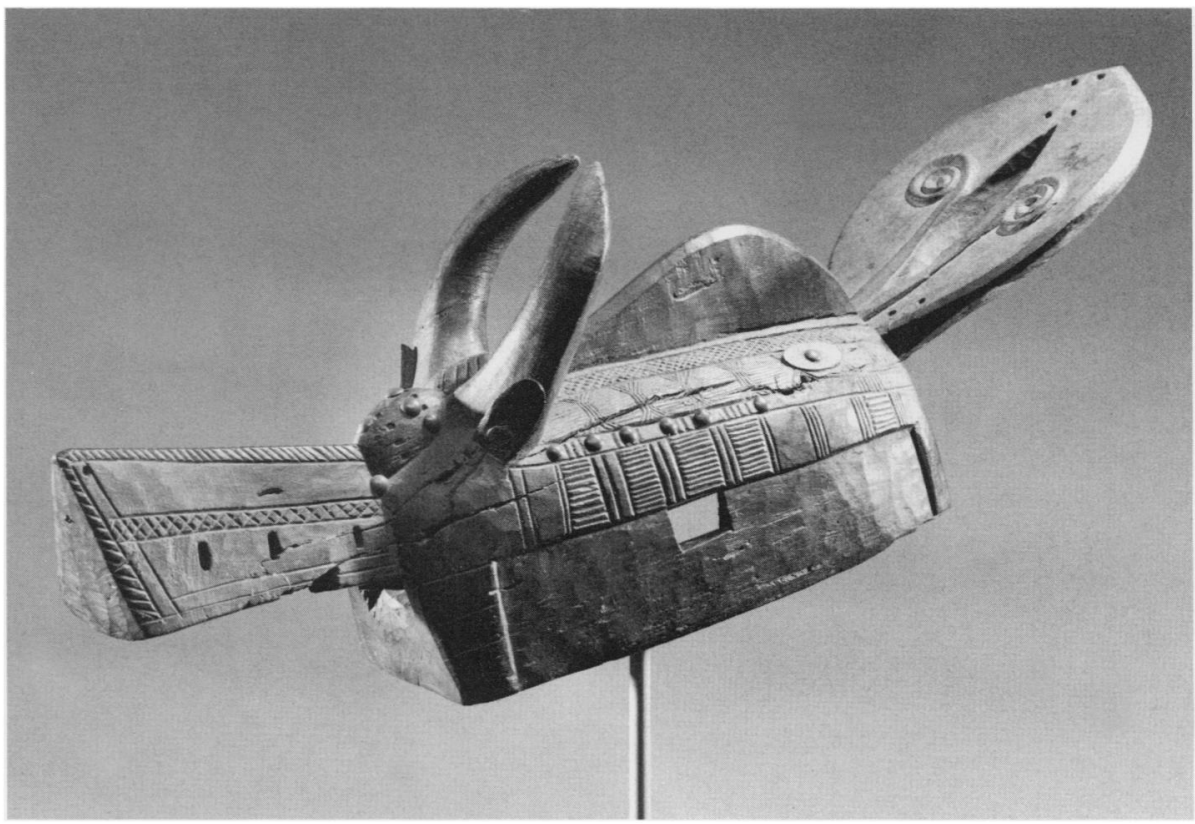


Also, the typeface is difficult to read. Still, Gardi and Engelbrecht have certainly accomplished what they set out to do-namely, collecting papers from anthropologists and art historians whose lives have been touched by Renée Boser-Sarivaxévanis's dedication to textiles and Africa.

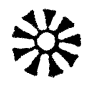

READING THE SKIN

Adornment, Display and Society among the Wahgi

Michael O'Hanlon

British Museum Publications, London, 1989. 164 pp., 12 b/w \& 16 color photos, 14 drawings, 1 chart, 2 maps, notes, bibliography, index. $£ 25$ hardcover.

Reviewed by Annette Lynch

Reading the Skin is a publication resulting from Michael O'Hanlon's doctoral dissertation research among the Wahgi people of the New Guinea Highlands between May 1979 and August 1981. The extensive corpus of good field photographs illustrating this volume will help to satisfy the hunger of those eager for a rare look at the rich traditions of dress in this area. The importance of O'Hanlon's book rests fundamentally on his recognition of how knowledge of the tradition of personal adornment and display contributes to understanding the culture of the people of Melanesia. Besides A. and M. Stratherns' research in Mount Hagen (SelfDecoration in Mount Hagen, 1971), few working in New Guinea have recognized and taken advantage of the wealth of cultural information provided by the dressed body.

O'Hanlon's opening comments both introduce the Wahgi and locate his study within the larger body of anthropological research that has been conducted in the South Pacific. His attempt to answer the seemingly simple question "Who are the Wahgi?" makes clear the difficulty inherent in attempts to draw distinct boundaries around cultural groups. Maria Reay's earlier studies of the Wahgi, from a monograph published in 1959 to an article published in 1974, were drawn from fieldwork conducted among the southern Wahgi, whom she calls the Kuma. O'Hanlon instead elects to refer to people living both north and south of the Wahgi River as Wahgi. This decision is based on linguistic and cultural similarities (similarities also acknowledged in Reay's work) as well as current indigenous usage. $\mathrm{O}^{\prime}$ Hanlon largely confirms Reay's earlier analysis and states that his intent "is to draw upon this substantially agreed background to analyze an area of Wahgi life-adornment and display-that Reay's more global monograph was not able to treat in detail" (p. 12). More significantly, $\mathrm{O}^{\prime}$ Hanlon declares that one of his two goals is to "situate a fuller account of one tradition of adornment and display nearer the centre of ethnographic analysis" (p. 16).
O'Hanlon's second goal, also stated in his opening comments, is to "offer an interpretation" of how the relationship between aesthetics and ethics characterizes adornment and display among the Wahgi (p. 17). Central to this interpretative approach is the fact that the Wahgi consider the aesthetic quality of a display to be enhanced or compromised by the relative moral status of the group performing it. Aesthetic evaluation criteria such as the number of men performing, their appearance, and their bearing are all thought to be affected by whether the group has successfully maintained crucial intragroup relationships. O'Hanlon argues that as the audience compares and contrasts ideal intragroup relationships with actual political life, as symbolically displayed by the performing group, the meaning of adornment and display emerges.

Reading the Skin is informally divided into halves. The first section provides the ethnographic background for the second, which concentrates on the dressed body. The first half of the book contains four chapters. Chapter 1 discusses group structure; chapter 2 , marriage; chapter 3 , intragroup relationships; and chapter 4 , the three major contexts for adornment and display: the Pig Festival, intergroup payments, and warfare. The second half is divided into three sections focused on adornment and display. Chapter 5 describes the varieties of displays, chapter 6 focuses on the evaluation process, and chapter 7 offers $\mathrm{O}^{\prime}$ Hanlon's interpretations.

O'Hanlon's decision to divide the book into two sections, with the first part providing an ethnographic context for the second, is, in my opinion, unfortunate. For one thing, this structure is simply frustrating. The reader genuinely interested in the dressed body has to read over half of the book before the subject is directly addressed. More significantly, such an arrangement contributes to the book's failure to fulfill its stated goal of building an interpretation of the Wahgi around a central focus of adornment and display. The placement of the bulk of the adornment material at the end of the book effectively negates $\mathrm{O}^{\prime}$ Hanlon's introductory claim that adornment and the evaluation of it play a central role in Wahgi social and cultural life.

Reading the Skin will hold particular appeal for those interested in cultural aspects of the dressed body and its assessment. Specialists in the South Pacific and New Guinea will appreciate the detailed early chapters on social structure, as well as the precise descriptions and analyses in the later chapters on adornment and display. The value of Reading the Skin for classroom use is seriously compromised, however, by its failure to integrate the background information on the Wahgi contained in the first section with the adornment material in the second.

$\mathrm{O}^{\prime}$ Hanlon's struggle for the right language to use when referring to the dressed body confirms the relevance of a paper by Mary Ellen Roach-Higgins and Joanne Eicher on a classification system of dress encom- passing both modifications of and supplements to the body ("The Anthropology of Dress and Gender," in Dress and Gender: Making and Meaning, forthcoming). His use of the term "ethnographic arts" throughout the book points toward the continuing need to find better ways of referring to what were once called the "primitive arts."

O'Hanlon originally went to the New Guinea Highlands to study adornment and display among $\mathrm{Ni}$-speaking people to the west of the Wahgi. After he got to the field, he recognized the value of documenting the visually rich Pig Festival among the Wahgi. The body of photographic images in this publication, from that festival and other occasions of adornment, pays apt testimony to O'Hanlon's ability to recognize a good research opportunity and take advantage of it. Despite my reservations, he should be commended for his ability to perceive the analytic potential of the dressed body and its assessment by others.

\section{notes}

BERNS \& SIEBER: Notes, from page 39

1. We prepared our list of invitees to these memorial issues to the best of our knowledge; we apologize to anyone we may have inadvertently overlooked.

2. The Arts of the Benue River Valley (forthcoming) will be published by the UCLA Fowler Museum of Cultural History in conjunction with a major exhibition of the same name.

3. Although this essay remains unpublished, many of its salient ideas are included in Rubin's Art as Technology: The Arts of Africa Oceania, Native America and Southern California (1989). See especially Pearlstone's essay, "Convergence,"

pp. 149-62.

For more on this research, see Rubin 1979

5. Research on Forest Lawn is published in B. Rubin, $\mathrm{R}$ Carlton, and A. Rubin's L.A. in Installments (1979), which was intended to be the first of a series of publications on Los Angeles culture and history.

References cited

Drewal, H. 1990. "African Art Studies Today," in African Art Studies: The State of the Discipline. Washington, DC: National Museum of African Art.

Rubin, A. (Z. Pearlstone, ed.). 1989. Art as Technology: The Arts of Africa, Oceania, Native America and Southern California. Beverly Hills, CA: Hillcrest Press.

Rubin, A. 1979. "Anthropology and the Study of Art in Contemporary Western Society: The Pasadena Tournament of Roses," in The Visual Arts: Plastic and Graphic, ed. Justine Cordwell, pp. 669-716. The Hague.

Rubin, A. 1972. "Art as Technology in Sub-Saharan Africa Rubin, A. 1972. "Art as Technology in Sub-Sah
and Southern California." Unpublished ms.

Rubin, A. (ed.). 1988. Marks of Civilization: Artistic Transformations of the Human Body. Los Angeles: Museum of Cultural History, UCLA.

Rubin, A. and M. Berns (eds.). Forthcoming. The Arts of the Benue River Valley. Los Angeles: Fowler Museum of Cultural History, UCLA.

Rubin, B., R. Carlton, and A. Rubin. 1979. L.A. in Installments: Forest Lawn. Santa Monica, CA: Westside Publications.

McNAUGHTON: Notes, from page 53

This research was made possible by a National Endowment for the Humanities Summer Stipend and a one-semester sabbatical from Indiana University. I am grateful to both institutions. Marla Berns, Kate Ezra, Diane Pelrine, and Roy Sieber offered extensive advice after reading an earlier draft, for which I thank them heartily. I also wish to than Which I thank then Girshick Ben-Amos, Charles Bird, Suzanne Blier, Kathy Curnow, Martha Kendall, Abu Nasara, Philip Ravenhill, Raymond Silverman, and Monica Visonà for their thoughts and suggestions at various stages of the work. For the generous use of their photographs, I want to thank the Arnold Rubin Archives, Toby Hecht, Abu Nasara, Christopher Roy, and Roy Sieber. Finally I offer my appreciation to Monn Adams for providing me a copy of her master's thesis. 
1. Curnow notes that the town was originally Nupe, but so many Yoruba have moved in that it now has two sides: Share, which is Yoruba, and Tsaragi, which is Nupe (pers. com., 1990).

2. I thank Monica Visonà for alerting me to this photograph. 3. The horizontal masks in the southern Nigeria area (such as the Abua, Igbo, ljo, and Yoruba versions) are very different compositionally from the masks in northern Nigeria and those to the west. Sieber and Thompson have referred to them in lectures as being part of a West African coastal Creek International Style fostered by coastal trade.

4. This constitutes another distinction between the masks I am considering and these southern masks. In these southern traditions there are pantheons of depicted characters, many of which are animals. Horizontal masks in the northern belt are usually not part of such extensive mask pantheons, nor are they generally one of many animal portrayals.

5. See, for example, Hersak on the Bwadi Bwa Kifwebe society of the Songye (1985:42-46), and Vogel on the Goli masks of the Baule (1977:124-52).

6 . I have derived the synopsis in this section from a survey of the literature in my bibliography. While I have disassociated all this information from specific masks for the purposes of this paper, an important part of the research will be to examine them closely together.

7. This sort of idea was also taught in introductory art history survey courses in the 1960 s to explain the passages between major epochs in Western art.

8 . For discussions of theoretical aspects of representations see Rabinow (1986) and Sperber (1985). For an examination of representations in action see Ben-Amos (1976).

9. Of course, many also felt that in isolation, formal analysis can be an elitist waste of time.

10. For more on the idea of transaction in psychology and social discourse see Bruner (1986:57-69).

References cited

Adams, Marie Jeanne (Monni). 1963. "The Distribution and Significance of Composite Animal-Headed Masks in African Sculpture." Master's thesis, Columbia University. Arnoldi, Mary Jo. 1983. "Puppet Theatre in the Segu Region in Mali." Ph.D. dissertation, Indiana University.

Barnes, Sandra T. 1986. Patrons and Power: Creating a Political Community in Metropolitan Lagos. Bloomington: Indiana University Press.

Bastin, Marie-Louise. 1985. Escultura africana em Portugal. Trans. Antonio Enes Ramos. Lisbon: Instituto de Investigacão Científica Tropical, Museu de Etnologia.

Baxandall, Michael. 1985. Patterns of Intention: On the Historical Explanation of Pictures. New Haven: Yale University Press.

$\rightarrow$ Ben-Amos, Paula. 1977. "Pidgin Languages and Tourist Art," Studies in the Anthropology of Visual Communication 4, 2:128-39.

Ben-Amos, Paula. 1976. "Men and Animals in Benin Art," Man n.s. 2, 2: 243-52

Biebuyck, Daniel. 1985. The Arts of Zaire: Volume 1: Southwestern Zaire. Los Angeles: University of California Press.

Bourgeois, Arthur P. 1984. Art of the Yaka and Suku. Meudon: Alain et Francoise Chaffin.

Bravmann, René A. 1974. Islam and Tribal Art in West Africa. Cambridge: Cambridge University Press.

Bravmann, René A. 1973. Open Frontiers: The Mobility of Art in Black Africa. Seattle: University of Washington Press.

Bruner, Jerome. 1986. Actual Minds, Possible Worlds. Cambridge: Harvard University Press.

Brussels. Tourist Bureau for the Belgian Congo and RuandaUrundi. 1956. Traveller's Guide to the Belgian Congo and the Ruandi-Urundi.

Cannes. Conseil Permanent des Expositions de Propagande Touristique et Culturelle. 1957. Arts d'Afrique et d'Océanie.

Carroll, Kevin. 1966. Yoruba Religious Carving: Pagan and Christian Sculpture in Nigeria and Dahomey. New York: Frederick A. Praeger

Celenko, Theodore. 1983. A Treasury of African Art from the Harrison Eiteljorg Collection. Bloomington: Indiana University Press.

Cole, Herbert M., and Chike C. Aniakor. 1984. Igbo Arts: Community and Cosmos. Los Angeles: UCLA Museum of Cultural History.

Cole, Herbert M., and Doran H. Ross. 1977. The Arts of Ghana. Los Angeles: UCLA Museum of Cultural History.

Cornet, Joseph. 1978. A Survey of Zairian Art: The Bronson Collection. Trans. Matt McGaughey, Raleigh: North Carolina Museum of Art.

Cornet, Joseph. 1975. Art from Zaire: 100 Masterworks from the National Collection. Trans. Irwin Hersey. New York African-American Institute.

Cornet, Joseph. 1971. Art of Africa: Treasures from the Congo. Trans. Barbara Thompson. London: Phaidon.

Curnow, Kathy. 1983. "The Afro-Portuguese Ivories: Classification and Stylistic Analysis of a Hybrid Ar Form." 2 vols. Ph.D. dissertation, Indiana University.

de Sousberghe, Leon. 1958. L'art pende. Brussels: Academie Royale de Belgique.

DeMott, Barbara. 1979. Dogon Masks: A Structural Study of Form and Meaning. Ann Arbor: University Microfilms International.

Drewal, Henry John and Margaret Thompson Drewal. 1983 Gelede: Art and Female Power among the Yoruba. Bloomington: Indiana University Press.
Drewal, Henry J., John Pemberton III, and Rowland Abiodun. 1989. Yoruba: Nine Centuries of African Art and Thought. New York: The Center for African Art and Harry Abrams.

Erekosima, Tonye Victor and Joanne Bubolz Eicher. 1981. "Kalabari Cut-Thread and Pulled-Thread Cloth: An Example of Cultural Authentication," African Arts 14 2:48-51, 87

Ezra, Kate. 1986. A Human Ideal in African Art: Bamana Figurative Sculpture. Washington, DC: National Museum of African Art.

Félix, Marc L. 1987. 100 Peoples of Zaire and Their Sculpture: The Handbook. Brussels: Zaire Basin Art History Research Foundation.

Fivaz, Derek and Patricia E. Scott. 1978. African Languages: $A$ Genetic and Declimalised Classification for Bibliographic and General Reference. Boston: G.K. Hall \& Co.

Fortier, J. 1958-60. "Les masques de l'initiation chez les Mbaye-Moissala," Notes Africaines 67(July):82-85.

Fortier, J. 1958. "Ties et coutumes d'une tribu sara, les Mbaye de Moissala," Bulletin de l'I.F.A.N. ser. B, 20, 1-2:142-69.

Frank, Barbara. 1981. Die Kulere: Bauern in Mittelnigeria. Wiesbaden: Steiner.

Fraser, Douglas. 1962. "The Legendary Ancestor Tradition in West African Art," in African Art as Philosophy, ed. Douglas Fraser, pp. 38-53. New York: Interbook.

Gaisseau, Pierre-Dominique. 1954. Sacred Forest: Magic and Secret Rites in French Guinea. Trans. Stephen Becker. New York: Alfred A. Knopf

Galhano, Fernando. 1968. Escultura africana no Museu de Etnologia do Ultramar. Lisbon: Junta de Investigaçoes do Ultramar

Gallois-Duquette, Danielle. 1983. Dynamique de l'art bidjogo. Lisbon: Instituto de Investigacão Cientifica Tropical.

Geary, Christraud, and Adamou Ndam Njoya. 1985. Mandu Yenu: Bilder aus Bamum, einem westafrikanischen Konigreich. Munich: Trickster

Glaze, Anita J. 1981. Art and Death in a Senufo Village. Bloomington: Indiana University Press.

Gombrich. E. H. 1978. "Visual Metaphors of Value in Art," in his Meditations on a Hobby Horse, pp. 12-29. London Phaidon.

Goodman, Nelson. 1984. Of Mind and Other Matters. Cambridge: Harvard University Press.

Green, Kathryn. 1986. "Dyula and Sonongui Roles in the Islamization of Kong," Asian and African Studies 20:103-23.

Greenberg, Joseph H. 1966. Languages of Africa. 2nd ed. Bloomington: Indiana University Press.

Harms, Robert. 1987. Games against Nature: An Eco-Cultural History of the Nunu of Equatorial Africa. Cambridge Cambridge University Press.

Hersak, Dunja. 1985. Songye Masks and Figure Sculpture. London: Ethnographica.

Herskovits, Melville J. 1967. Dahomey: An Ancient West African Kingdom. 2 vols. Evanston: Northwestern University Press.

Himmelheber, Hans. 1960. Negerkunst und Negerkunstler.

Braunschweig: Klinkhardt \& Biermann.

Holas, Bernard. 1980. Traditions krou. France: Fernand Nathan.

Holas, Bohumil. 1948. "Le masque Komo de Korodou," Notes africaines 38:24-25

Holquist, Michael. 1981. The Dialogic Imagination: Four Essays by M. M. Bakhtin. Austin: University of Texas Press.

Huet, Michel. 1978. The Dance, Art and Ritual of Africa. New York: Pantheon.

Jones, G. I. 1988. "The Niger-Cross River Hinterlands and Their Masks," in West African Masks and Cultural Systems, ed. Sidney Littlefield Kasfir, pp. 109-22. Tervuren: Musée Royal de l'Afrique Centrale.

Jones, G.I. 1984. The Art of Eastern Nigeria. Cambridge

Cambridge University Press.

Kecskési, Maria. 1982. Kunst aus dem alten Afrika. Innsbruck: Pinguin-Verlag.

Kjersmeier, Carl. 1935. Centres de style de la sculpture negre africaine. 4 vols. Copenhagen: Vald. Pedersens Bogtrykkeri reprint ed., New York: Hacker Art Books, 1967.

Kouadio Aka, Martin. 1982. "L'Art Agni du Moronou," Godo-Godo (Abidjan: Université Nationale de Côte d'Ivoire, I.H.A.A.) 8:67-111.

Kreamer, Christine Mullen. 1986. Art of Sub-Saharan Africa: The Fred and Rita Richman Collection. Atlanta: High Museum of Art.

Krieger, Kurt and Gerdt Kutscher. 1967. Westafrikanische Masken. 2nd ed. Berlin: Museum für Völkerkunde.

Kuhn, Thomas S. 1970. The Structure of Scientific Revolutions. Chicago: University of Chicago Press.

Lamp, Frederick. 1986. "The Art of the Baga: A Preliminary Inquiry," African Arts 19, 2:64-67, 92.

Le Herissé, A. 1911. L'ancien royaume du Dahomey. Paris: E. Larose.

Leuzinger, Elsy. 1963. Afrikanische Skulpturen/African Sculpture: A Descriptive Catalogue. Trans. Ann E. Keep. Zurich: Atlantis.

MacCormack, Carol P. 1980. "Art and Symbolism in Thoma Ritual among the Sherbro, Sierra Leone," Ethnologischrift Zurich 1:151-61.

McNaughton, Patrick R. 1988. The Mande Blacksmiths: Knowledge, Power, and Art in West Africa. Bloomington Indiana University Press.

McNaughton, Patrick R. 1979. Secret Sculptures of Komo: Art and Power in Bamana (Bambara) Initiation Associations.

Philadelphia: Institute for the Study of Human Issues.

Murdock, George Peter. 1959. Africa: Its Peoples and Their Culture History. New York: McGraw-Hill.

Neyt, François. 1985. The Arts of the Benue: To the Roots of Tradition. Belgium: Editions Hawaiian Agronomics.

Northern, Tamara. 1984. The Art of Cameroon. Washington DC: Smithsonian Institution Press.

Paulme, Denise. 1962. African Sculpture. Trans. Michael Ross. New York: Viking Press.

Pelrine, Diane. 1988. African Art from the Rita and John Grunwald Collection. Bloomington: Indiana University Art Museum

Prouteaux, Maurice. 1918-19. "Notes sur certains rites magico-religieux de l'Haute Côte d'Ivoire," L'Anthropologie 29:37-52

Rabinow, Paul. 1986. "Representations Are Social Facts: Modernity and Post-Modernity in Anthropology," in Writing Culture, eds. James Clifford and George E. Marcus, pp. 234-61. Berkeley: University of California Press.

Ravenhill, Philip L. 1988. "An African Triptych: On the Interpretation of Three Parts and the Whole," Art Journal 47, 2:88-94.

Ravenhill, Philip L. 1980. Baule Statuary Art: Meaning and Modernization. Philadelphia: Institute for the Study of Human Issues.

Roberts, Allen F. and Evan M. Maurer (eds.). 1985. The Rising of a New Moon: A Century of Tabwa Art. Ann Arbor: University of Michigan Museum of Art.

Roberts, Richard L. 1987. Warriors, Merchants, and Slaves: The State and the Economy in the Middle Niger Valley, 1700-1914. Stanford: Stanford University Press.

Roy, Christopher D. 1987. Art of the Upper Volta Rivers. Meudon: Alain et Françoise Chaffin.

Rubin, Arnold. 1978. "Buffalo Mask, Chamba, Nigeria," in Twenty-Five African Sculptures, ed. Jacqueline Fry, pp. 54-57. Ottawa: National Gallery of Canada.

Rubin, Arnold. 1969. "The Arts of the Jukun-Speaking Peoples of Northern Nigeria." 2 vols. Ph.D. dissertation, Indiana University.

Ruel, Malcolm. 1969. Leopards and Leaders: Constitutional Politics among a Cross River People. London: Tavistock Publications.

Ruel, Malcolm. 1965. "Witchcraft, Morality and Doubt," Odu (University of Ife Journal of African Studies) 2:3-26.

Sargent, R. A. 1988. "Igala Masks: Dynastic History and a Face of the Nation," in West African Masks and Cultural Systems, ed. Sidney L. Kasfir, pp. 17-44. Tervuren: Musée Royal de l'Afrique Centrale.

Schwartz, Nancy Beth A. n.d. Mambilla-Art and Material Culture. Milwaukee: Milwaukee Public Museum

Secret Museum of Mankind. n.d. 5 vols. in 1. Vol.2, The Secret Museum of Africa. New York: Manhattan House.

Sieber, Roy. 1974. Interaction: The Art Styles of the Benue River Valley and East Nigeria. West Lafayette: Purdue University Gallery.

Sieber, Roy. 1961. Sculpture of Northern Nigeria. New York: Museum of Primitive Art.

Skougstad, Norman. 1978. Traditional Sculpture from Upper Volta: An Exhibition of Objects from New York Museums and Private Collections. New York: African-American Institute.

Sperber, Dan. 1985. "Anthropology and Psychology: Towards an Epidemiology of Representations,". Man n.s. 20:73-89.

Sydow, Eckart von. 1954. Afrikanische Plastik. Berlin: Gebruder Mann.

Tauxier, Louis. 1921. Le noir de Bondoukou. Paris: E. Leroux.

Thomas, Northcote W. 1916. Anthropological Report on Sierra Leone. Part I. Law and Custom of the Timne and Other Tribes. London: Harrison \& Sons.

Thompson, Robert Farris. 1974. African Art in Motion: Icon and Act in the Collection of Katherine Coryton White. Los Angeles: University of California Press.

Thompson, Robert Farris. 1973. "Yoruba Artistic Criticism," in The Traditional Artist in African Societies, ed. Warren L. d'Azevedo, pp. 19-61. Bloomington: Indiana University Press.

Todorov, Tzvetan. 1984. Mikhail Bakhtin: The Dialogical Principle. Trans. Wlad Godzich. Minneapolis: University of Minnesota Press.

Tong, James Yingpeh. 1967. African Art in the Mambila Collection of Gilbert D. Schneider. Athens, $\mathrm{OH}$ : James Yingpeh Tong.

Trowell, Margaret. 1964. Classical African Sculpture. New York: Praeger.

Underwood, Leon. 1964. Masks of West Africa. London: Alec Tiranti.

Van Geertruyen, Godelieve. 1976. "La fonction de la sculpture dans une société africaine: Les Baga, Nalu et Landuman (Guinée)," Africana Gandensia (Gent) 1:63-117.

Vansina, Jan. 1984. Art History in Africa: An Introduction to Method. London: Longman. 
Volprecht, Klaus. 1972. Sammlung Clausmeyer Afrika. Cologne: E. J. Brill.

Weeks, John H. 1914. Among the Primitive Bakongo. London: Seeley, Service \& Co.

Weston, Bonnie E. 1984. "Northeastern Region," in Igbo Arts: Community and Cosmos, by Herbert M. Cole and Chike C. Aniakor, pp. 145-61. Los Angeles: UCLA Museum of Cultural History.

Willett, Frank. 1971. African Art: An Introduction. London: Thames \& Hudson

Williams, Drid. 1968. "The Dance of the Bedu Moon," African Arts 2,1:18-21, 72.

Wittmer, Marcilene K., and William Arnett. 1978. Three Rivers of Nigeria. Atlanta: High Museum of Art.

\section{BLACKMUN: Notes, from page 65}

During the long-term study of Benin altar tusks I have been aided by the support and scholarship of many generous individuals and organizations. I would particularly like to thank Professor and Mrs. Philip Dark for hospitality and assistance in sharing their detailed files of photographs and notes concerning altar tusks. On several occasions, William Fagg also offered his informal impressions of various tusk types, based upon his long familiarity with the art of Benin. A UCLA Dickson History of Art Travel grant made it possible to chart the surfaces of Benin altar tusks in museum and private collections in 1980, and I acknowledge the assistance of collectors, curators, and researchers who have been of help in personal as well as professional ways. Organization of the motif data would have been much more difficult without the professional help of computer specialist Michael Roland, aided by my husband, Rupert Blackmun, who has supported my endeavors in every possible way. I was extremely fortunate to have worked with the late Arnold Rubin, who served as my dissertation advisor, offering unfailing encouragement and considerable inspiration. Fieldwork in Benin City was financed by a 1981-82 Fulbright Dissertation Research Grant. Dr. Ekpo Eyo provided affiliation with the Nigerian Department of Antiquities, and Professor S.I. Wangboje offered facilities at the University of Benin. Paula Girshick Ben-Amos and Dan Ben-Amos gave me guidance and assistance in the field that was invaluable. I also owe gratitude to many specialists in the traditional knowledge of Benin, especially Chief Ohanbanmu Ineh and David Omoregie and their fellow artists in the Igbesanmwan. I especially wish to thank his Highness Oba Erediauwa, the Oba of Benin. Without his interest, advice, patience, and generosity during my work with the officials of his court, iconographic study of the tusk motifs would have been impossible.

1. Traditionally, there are three grades of carvers within the guild: iroghae, the least skilled craftsmen who are learning the trade; urhonigbe, the artists who are initiates of the Iwebo palace association and do most of the carving for the Oba, and ekhaemwe-oba, the elders who hold the titles of Eholor, Obasoyen, and Ineh, in order of their rank (P. Ben-Amos 1971:68-69). In the past there was also specialization based upon the carving medium: when Roupell spoke to members of the Igbesanmwan at the turn of the century, the Ineh identified himself as "Master Ivory Carver" and the Eholor as "Master Wood Carver" (Read \& Dalton 1899:4). At the present time the two upper titles are inactive, and the guild is led by the Ineh.

2. Ryder has identified the ruler visited by Landolphe as "almost certainly Akengbuda" (1969:203). Bradbury has credited Egharevba with determining historical dates fairly accurately from 1715 onward (1973:41).

3. Ewuakpe founded a new lineage of kings after the interregnum of the 1600 s, and the heraldic motifs on Benin's eighteenth- and nineteenth-century royal altar tusks include new dynastic insignia, as well as ancient emblems revived to associate his heirs with the sixteenth-century warrior kings (see Blackmun 1990). The direct lineage of these earlier kings ended with Ohuan (ca. 1610-30)

4. In one of Bradbury's unpublished notes (n. 114) he recorded a communication by Chief Osuma on April 14, 1958. The information included the comment that "the Oba wore a mask at his waist on only one occasion: Ugi'Iye" (Ugie lye Oba), when he worshiped the spirit of his deceased mother. He would dress in "the full regalia of a high-ranking chief" for this ceremony. In the case of the Oba this "full regalia" probably consisted of lyerhuan (the udaeha band of beads on his forehead, a high odigba beaded collar, and a wrapped skirt with quantities of beads over the chest and arms) rather than the full-length Ehaenegbehia made of overlapping scallops of red ododo flannel that is associated in Benin with prominent town chiefs. Yet this information should be evaluated in the context of several photographs recently published by Rowland Abiodun of the Ojomo of Ijebu-Owo wearing a crown of red coral beads and a full-length red flannel costume called Orufanran that resembles the Ehaenegbehia of Benin. Among the "potent attachments" sewn to the Ejomo's red costume is an ivory mask very similar to ivory "pendants" taken from Benin in 1897. Although these ivory face masks vary greatly in size and style, the largest, and probably the oldest type (Fig. 12) is associated in some way with Idia. The long political and economic association of Benin and Owo has led to customs and concepts that are shared, although with differing traditional rationalizaare shared, although with differing traditional rationaliza-
tions. Abiodun remarks that in Owo, the ivory pendant amulets worn by the Ojomo are "related to war, protection, and success" (Abiodun 1989:103, fig. 105).

5. These four are the Egerton-Plass bell, now in the British Museum; the Roupell-Epstein bell, recently in Amsterdam; the Rawson bell in the National Museum at Lagos, Nigeria; and the Pitt-Rivers bell in the Brooklyn Museum.

6 . In an unpublished study completed in 1979 , Wendy Schoenfeld located nine pre-1897 ivory pendant masks. The well-known example in London (Fig. 12) and its counterpart in New York are the largest and the most naturalistic. Three others (Stuttgart, the Katherine White collection, and the Galway collection) are similar in size and may also date from the sixteenth century (Fagg 1968:fig. 141). The remainder (in Berlin, Cologne, Hamburg, and Lagos) are smaller and differ in their appearance, and their function is uncertain.

7. Interview in the Nigerian Observer with Akenzua II, November 15, 1956:1. Additional remarks on this topic by Akenzua were published by the Nigerian Observer on November 21, 1976:1, 2

8. According to Egharevba (1969:28,60), Eweka's mother, Eghaghe, was betrothed to a prominent citizen of Benin named Ogagun. Ovoranmwen, while still a prince, married Ogagun's daughter Arokun. He then fell in love with Eghaghe, and in spite of the fact that she was betrothed to his father-in-law, he took Eghaghe for his own wife. A son, whom some people considered illegitimate, was born of this union, and Ogagun named him Aiguobasinmwin. Resenting Ogagun's continued attempts to discredit Aiguobasimwin and his father Ovoranmwen, Oba Adolo forced Ogagun to commit suicide in 1882. In spite of the questionable circumstances of his birth, Aiguobasinmwin was chosen as the Edaiken, and he became Oba Eweka II on Ovoranmwen's death in 1914. Perhaps it was because of this controversy that the British, advised by Benin elders, did not allow Eweka to install his mother as the Iye Oba. Eghaghe died in 1933 , ten days after the death of her son, and was "buried by her grandson at Uselu in 1933, with the usual ceremonies for an Iy'oba" (Egharevba 1968:75)

The circumstances surrounding Ariowa, the mother of Akenzua II, are also unusual. She died while Akenzua was still a prince, and in 1935 he named her Iye Oba posthumously, two years after he had honored his grandmother (Egharevba 1968:64).

9. Barbot, for example, mentioned in the early 1700 s that when a new king killed his brother and his brother's children to prevent usurpation of his throne "all of them were buried with great pomp" (1732:372).

10. Bradbury has discussed some of the traditions of the Ezomo's lineage (1973:251-82), and other details can be found in Egharevba. Since not every Ezomo was equally wealthy or prominent, and since commissioning a matched set of altar tusks required payment in the form of slaves, wives, livestock, produce, currency, and cloth to the carvers (a considerable outlay of property), it is not too difficult to find the specific Ezomos in the lineage who would be capable of the enormous expense.

11. Philip Dark, in his ongoing analysis of the brass memorial heads used to support Benin's ancestral altar tusks, has constructed a chronology for these heads that directly concerns the tusks commissioned from 1816 onward. Calling attention to the established tradition in Benin that the crown with two wing-like extensions was introduced by Osemwende (1960:19), Dark has located approximately fifty heads that bear the double-winged crown (in Vogel 1981:139; cf. 48 heads in Dark 1975:table 5), and has reasoned that these winged-crowned heads must all have been cast after 1816, during the reigns of Osemwende, his son Adolo (ca. 1851-88), and his grandson Ovoranmwen (ca. 1888-97). At this stage of work on the figural altar tusks, I have located forty royal ivories that fit into this period (Sets V-VI-VII). I have assigned fourteen tusks to Ovoranmwen's reign as Set VII, because of their relatively fresh condition, and because their motifs correspond more closely to twentieth-century carving than do the motifs of any other royal sets. If my hypothesis is correct, the tusks of Set VII were seen during the carving stage in 1890 by an English visitor to Benin, Cyril Punch, and these may also be the tusks that Punch photographed in their palace shrine setting in 1891 (Roth 1903:figs. 79, 84, 196). Unfortunately, the published photographs are not clear enough to identify the key motifs. Fifteen tusks that are intermediate in motif choice between Ovoranmwen's Set VII and Osemwende's Set V have been designated Set VI and assigned to Adolo, who must have commissioned them about 1853. If Dark is correct, these forty tusks would all originally have been supported by brass heads wearing double-winged crowns.

The discrepancy between forty royal figural tusks from 1816-97 vs. fifty commemorative heads with winged crowns is not serious. Since Dark had located 135 figural tusks by 1981 (1981:139) and only 105 of them have yet been charted, it is reasonable that others remain to be classified in Sets $\mathrm{V}-\mathrm{VI}-\mathrm{VII}$. Moreover, tusks with guilloche bands may also have been placed on commemorative brass heads.

As for comparison of the number of altar sets that I have designated as royal with documentary information about the number of altars in Oba Ovoranmwen's palace, diaries of the members of the Punitive Expedition contain very little that concerns either the location of these altars or how many tusks were found on each one. The estimated number of royal altars was inconsistently given as seven (Read \& Dalton 1899:8) or thirteen (Roth 1903:184, fig. 180). Although it is reassuring that the seven royal altar sets emerging from

the present study correspond to one of these early estimates, some of the larger groups of tusks may represent ivories taken from several palace altars commissioned about the same time, by the same ruler.

If the Queen Mother tusks of Set IV are from Obanosa's altar honoring his mother Ose, however, these tusks may not have been supported by male commemorative heads with winged crowns at all, but by Queen Mother heads of Dark's Type 8. Dark has called attention to stylistic parallels between Type V winged crown heads and Type 8 Queen Mother heads (1975:48), and he has assigned fourteen of the latter to the altar honoring Ose (1975:61, fig. 2). Yet only six Queen Mother tusks of Set IV have been located, less than half the number that would correspond to Dark's fourteen examples. Moreover, Set IV tusks may be too large for these Queen Mother heads. Experimentation may be necessary to establish whether a Type 8 head could adequately balance a tusk measuring $52 \mathrm{~cm}$ in circumference, behind the protruding high crown. The dimensions of each Set IV tusk (the first figure is the

Tusk 20: Blackburn Museum, Blackburn; $194 \mathrm{~cm}, 45 \mathrm{~cm}$

Tusk 119: Reiss-Museum, Mannheim; $174 \mathrm{~cm}, 39 \mathrm{~cm}$.

Tusk 135: Tishman Collection; $118 \mathrm{~cm}, 43 \mathrm{~cm}$.

Tusk 136: Indiana University, Bloomington; $154 \mathrm{~cm}, 52 \mathrm{~cm}$.

Tusk 157: Etnografiska Museet, Stockholm; dimensions not recorded.

Tusk 56: National Museum, Lagos; $171 \mathrm{~cm}, 42 \mathrm{~cm}$.

12. Unfortunately, after surviving the 1816 fire, this large tusk was destroyed during World War II. Its motifs have been charted from the photograph in Luschan (1919:Tafel $113)$, where it was placed on the far left. Individual motif drawings from this tusk also appear in Plate $\mathrm{M}$ abb. 751

Plate P abb. 762a, Plate $Q$ abb. 766, Plate T abb. 785, and Plate U abb. 792. Luschan's generalized comments are on pages $462-63$

References cited

Allman, R. 1898. "With the Punitive Expedition to Benin City," The Lancet 2 (July 3): 43-44. London.

Abiodun, Roland. 1989. "The Kingdom of Owo," in Yoruba: Nine Centuries of African Art and Thought, by H. Drewal, J. Pemberton III, R. Abiodun. New York: The Center for African Art.

Akpata, A. 1937. "Benin: Notes on Altars and Bronze Heads," Ethnologia Cranmorensis 1: 5-10.

Auchterlonie, T. B. 1898. "The City of Benin: The Country, Customs, and Inhabitants," Transactions of the Sixth Annual Report of the Liverpool Geographical Society for the Year Ending 1897 1: 5-16.

Ayeni, Peter M. (ed.). 1975. Festivals of Bendel State. Benin City: Ministry of Home Affairs and Information.

Bacon, Reginald. 1897. Benin, City of Blood. London: Arnold.

Barbot, Jean, in A. Churchill. 1732. A Collection of Voyages and Travels 5:354-75. London.

Ben-Amos, Dan. 1975. Sweet Words: Storytelling Events in Benin. Philadelphia: Institute for the Study of Human Issues.

Ben-Amos, Paula Girshick. 1983. "In Honor of Queen Mothers," in The Art of Power: The Power of Art, eds. Paula Ben-Amos and Arnold Rubin, pp. 78-83. Los Angeles: Museum of Cultural History, UCLA.

Ben-Amos, Paula Girshick. 1980. The Art of Benin. New York: Thames \& Hudson.

Ben-Amos, Paula Girshick. 1971. "Social Change in the Organization of Wood Carving in Benin City, Nigeria." Ph.D. dissertation, Dept. of Anthropology, Indiana University.

Blackmun, Barbara W. 1990. "Obas' Portraits in Benin," African Arts 23,3: 61-69,102-4.

Blackmun, Barbara W. 1988. "From Trader to Priest in Two Hundred Years: The Transformation of a Foreign Figure on Benin Ivories," in "Object and Intellect: Interpretation of Meaning in African Art," Art Journal (summer), ed. Henry Drewal, pp. 128-38.

Blackmun, Barbara W. 1987. "Royal and Non-Royal Benin: Distinctions in Igbesanmwan Ivory Carving," in The Artist and the Workshop in Traditional Africa, Iowa Studies in African Art, ed. Christopher Roy, vol. 2, pp. 81-115.

Blackmun, Barbara W. 1985. Review of Kate Ezra, African Ivories, in African Arts 19, 1:12, 14, 88.

Blackmun, Barbara W. 1984a. Art as Statecraft: A King's Justification in Ivory. Geneva: Barbier-Mueller Museum.

Blackmun, Barbara W. 1984b. "The Iconography of Carved Altar Tusks from Benin, Nigeria." 3 vols. Ph.D. dissertation, Dept. of Art and Art History, UCLA.

Blackmun, Barbara W. 1983. "Reading a Royal Altar Tusk," in The Art of Power: The Power of Art, eds. Paula Ben-Amos and Arnold Rubin, pp. 59-70. Los Angeles: Museum of Cultural History, UCLA.

Bradbury, R. E. 1973. Benin Studies. London: Oxford University Press.

Bradbury, R. E. 1957-62. "BS Series: Benin Scheme Field Notes." Unpublished Documents, Special Collections, 